\title{
Analysis of journal content characteristics and metrics reported in the Clarivate Analytics Journal Citation Reports and Web of Science Core Collection Agricultural Engineering categories
}

\author{
Yuanjie Wang ${ }^{1,2}$, Philip W. Gassman ${ }^{3 *}$, Yingkuan Wang ${ }^{1 *}$, Yingjun $\mathrm{Pu}^{4}$ \\ (1. Chinese Academy of Agricultural Engineering Planning and Design, Beijing 100125, China; \\ 2. Agricultural Information Institute, Chinese Academy of Agricultural Sciences, Beijing 100081, China; \\ 3. Center for Agriculture and Rural Development, Iowa State University, Ames, IA 50011, USA; \\ 4. College of Mechanical and Electronic Engineering, Northwest A\&F University, Yangling 712100, China)
}

\begin{abstract}
The Clarivate Analytics Journal Citation Reports (JCR) and Web of Science (WoS) platforms are arguably the most influential journal citation/metric databases worldwide. Journals must first be indexed in the WoS Core Collection (CC) before being indexed in the JCR. The JCR and WoS platform are separate Clarivate Analytics products, but the JCR is included in the WoS platform for organizations that purchase both databases. The analysis for this study focused on citation data reported in the 2017 JCR (based on 2016 citation data) and other data reported in the WoS CC up to $2016 . \quad$ A total of 14 journals are indexed in the 2017 JCR agricultural engineering category; however, only 13 journals are analyzed in this because one journal was listed by mistake. Six of the 13 journals are published by large for-profit publishers (i.e., Elsevier B.V. or Springer Verlag) and the other seven are published by respective professional societies. The journals were analyzed as a function of type (specialty versus comprehensive), type of publisher and publication frequency, metrics such as the Journal Impact Factor (JIF), volumes of articles published by year and journal, and the source institutions and countries of published articles. Bioenergy- and industrial crop-focused journals included in the 2017 JCR agricultural engineering category manifest the strongest overall metrics, as evidenced by relatively high JIF scores: Bioresource Technology (4.917), Biomass and Bioenergy (3.219) and Industrial Crops and Products (3.181). In contrast, the highest JIF reported in the 2017 JCR for a comprehensive agricultural engineering journal was 2.044 for Biosystems Engineering. During 2006 to 2016, the number of articles indexed in the Core Collection for the JCR agricultural engineering category rose from 1,124 to 4,078, an increase of $263 \%$. Over $70 \%$ of the total articles published in 2016 were published in the three bioenergy- or industrial-crop focused journals. The top three countries that published the highest levels of WoS Core Collection agricultural engineering articles in 2016 were China (1132), United States (669) and Brazil (474). The similar top publishing institutions were the United States Department of Agriculture (USDA; 136), Chinese Academy of Sciences (CAS; 136) and Indian Council for Scientific and Industrial Research (CSIR; 79). The results of the study also show that publishing by Chinese scientists in the 13 journals indexed in the JCR Agricultural Engineering (AE) category is rapidly increasing, with seven research institutions ranked in the global top 20 in 2016, based on studies published in journals indexed in the JCR agricultural engineering category. The analysis also reveals that the specialty journals (e.g., the three bioenergy-focused journals) are not directly comparable with the comprehensive agricultural engineering journals and should potentially be excluded from future versions of the JCR and WoS $\mathrm{CC}$ AE categories.
\end{abstract}

Keywords: Web of Science, JCR, agricultural engineering, impact factor, USDA, CAS, comprehensive journals, specialty DOI: $10.25165 /$ j.ijabe. 20181105.3083

Citation: Wang Y J, Gassman P W, Wang Y K, Pu Y J. Analysis of journal content characteristics and metrics reported in the Clarivate Analytics Journal Citation Reports and Web of Science Core Collection Agricultural Engineering categories. Int J Agric \& Biol Eng, 2018; 11(5): 1-26.

\section{Introduction}

The origins of the field of Agricultural Engineering (AE) can be traced to early innovations developed by ancient civilizations,

Received date: 2017-04-26 Accepted date: 2018-09-15

Biographies: Yuanjie Wang, $\mathrm{PhD}$, Engineer, research interests: agricultural informatization, open access publishing, Email: wangyuanjie@caas.cn; Yingjun Pu, $\mathrm{PhD}$ candidate, research interests: agricultural robot, Email: puyj1987@163.com.

*Corresponding author: Philip W. Gassman, PhD, Environmental Scientist, research interests: water quality and environmental modeling. Email: pwgassma@iastate.edu; Yingkuan Wang, PhD, Research Professor, Postdoctoral Supervisor, research interests: agricultural mechanization and information, editing and publishing. Chinese Academy of Agricultural Engineering Planning and Design, 41 Maizidian Street, Chaoyang District, Beijing. $\quad$ Tel: +86-10-59197086, Email: wykford@188.com. including water technologies used by pre-Roman cultures ${ }^{[1]}$, irrigation systems developed in Mesopotami ${ }^{[2]}$ and Mesoamerica ${ }^{[3]}$, the use of channels, tunnels and aqueducts in Etruscan ${ }^{[4]}$ and Roman $^{[5]}$ cultures, agricultural terraces in Mesoamerica ${ }^{[6]}$ and wooden wheat harvesting machines used in the Roman Empire ${ }^{[7]}$. The influence of engineering in agriculture expanded during the industrial age, as evidenced by more advanced agricultural machinery such as the mechanical reaper ${ }^{[8]}$, seed drill and horse drawn hoe ${ }^{[9]}$ and improved horse drawn plows ${ }^{[7,9]}$, cotton $\operatorname{gin}^{[10]}$, steam plow and combine harvester ${ }^{[11]}$, and other machinery ${ }^{[7]}$.

The Agricultural Engineers Association, a trade group established in 1875 to represent agricultural machinery manufacturers and distributors in the United Kingdom ${ }^{[12]}$, is likely one of the first organizations to formally the term "agricultural engineering". The first university AE Department was established 
in 1905 at Iowa State University ${ }^{[13]}$, followed by numerous similar departments at other U.S. Land Grant Institutions ${ }^{[14-17]}$. Similar development of the AE field occurred in other countries, such as the Institute of Agricultural Engineering (IAE) that was formed in 1924 at Oxford University in the United Kingdom that later evolved into the Silsoe Research Institute ${ }^{[18,19]}$. The origins of modern AE education in China occurred in the late 1940s, which included educational exchanges and other interactions with U.S. universities and companies ${ }^{[20,21]}$. These developments led to the establishment of the first Chinese university AE departments and colleges during the early $1950 \mathrm{~s}^{[22]}$.

The first reported AE society was the American Society of Agricultural Engineers (ASAE), which was established in 1907, and later evolved into the American Society of Agricultural and Biological Engineers in $2005^{[13]}$. Various societies and related groups later formed to support the discipline in different countries and regions, such as the European Society of Agricultural Engineers (EurAgEng) ${ }^{[23]}$, Chinese Society of Agricultural Engineering (CSAE $)^{[24]}$ and the Society for Engineering in Agriculture in Australia (SEAg) ${ }^{[25]}$. At present, 33 such organizations are members of the International Commission of Agricultural Engineering (CIGR) $)^{[26]}$, which was formed in 1930 at the First International Congress of Agricultural Engineering (CIGR) ${ }^{[27]}$.

The first AE journal identified in the literature was Agricultural Engineering, which ASABE started publishing in $1920^{[28]}$ (and which later evolved into more of a news magazine until publication ceased in 1994). The society later started publishing Transactions of the ASAE in $1958^{[29]}$, which became Transactions of the ASABE in 2006, and added Applied Engineering in Agriculture in $1985^{[30]}$. The official journal of EurAgEng is Biosystems Engineering ${ }^{[[31]}$, which was previously called the Journal of Agricultural Engineering Research between 1956 and $2001^{[32]}$. Over 30 other AE journals are currently published including the International Journal of Agricultural and Biological Engineering ${ }^{[33]}$, Canadian Biosystems Engineering ${ }^{[34]}$, Agricultural Engineering International: CIGR Journal ${ }^{[35]}$, Journal of Agricultural Engineering ${ }^{[36]}$ and Engenharia Agrìcola ${ }^{[37]}$.

The majority of the journals published within the AE field can be termed "comprehensive AE" journals, which refers to the wide range of disparate sub-disciplines that are represented within the overall field such as: (1) animal, plant and facility systems; (2) power and machinery systems; (3) natural resources and environmental systems; (4) biosystems, biological and ecological engineering; and (5) agro-product and food processing systems ${ }^{[33]}$. There is some overlap in research topics that are relevant to various agricultural sub-disciplines as discussed below in Section 2.1, but most of the broad sub-disciplines are generally distinct fields which results in limited cross-interaction with other major agricultural engineering sub-disciplines. Thus comprehensive AE journals are relatively unique publishing platforms within the overall domain of scientific journals, due to the extremely broad range of sub-topics that are covered in such journals.

Dozens of metrics have been developed over the past several decades to provide different measures of the relative influence of specific scientific journals including AE journals ${ }^{[38-44]}$. The most influential of these metrics is the journal impact factor (JIF), which was initially introduced in conceptual ${ }^{[45]}$ and prototype ${ }^{[46]}$, and was later formally incorporated within the first Journal Citation Report (JCR) that was published in $1975^{[47]}$, as part of the overall data reported by the Institute for Scientific Information (ISI) that Dr. Eugene Garfield started in $1960^{[47]}$. The Thomson Corporation (which later became Thomson Reuters) purchased ISI along with the JCR and other citation products in $1992^{[48]}$. Several of those key citation products were eventually included in Thomsen Reuter's Web of Science (WoS) platform, which they sold in 2016 along with related products to two private equity funds ${ }^{[49]}$. As a result, a new firm called Clarivate Analytics was formed ${ }^{[50]}$, which currently manages the WoS platform including the JCR and related citation databases.

The current WoS platform consists of two major databases referred to as the Core Collection (CC) and All Databases, the latter of which includes CC-indexed journals as well as additional journals (and citations) recorded in several other specialist and regional indexing databases; e.g., BIOSIS Citation Index, CAB Abstracts, Inspec, and the Chinese Science Citation Database ${ }^{[51]}$. The WoS CC contains citation data for over 18000 journals in four main databases ${ }^{[51]}$ : Science Citation Index Expanded (SCIE), Social Science Citation Index (SSCI), Arts \& Humanities Citation Index (AHCI) and the Emerging Sources Citation Index (ESCI). Selected books and conference proceedings articles are also indexed in the $\mathrm{CC}$ via the Conference Proceedings Citation Index (CPCI) and Book Citation Index ${ }^{[51]}$. The CPCI is further partitioned into the Conference Proceedings Citation Index, Science (CPCI-S) and Conference Proceedings Citation Index, Social Science and Humanities (CPCI-SSH) ${ }^{[52,53]}$. The 2017 JCR, which reports 2016 citation data and is a component of the $\mathrm{WoS}^{[54]}$, consists of a total of 11459 journals indexed in the SCIE and/or SSCI in one or more of 236 topical categories in the $\mathrm{JCR}^{[55]}$. Over 8850 and 3200 journals are indexed in the respective SCIE and SSCI databases according to Clarivate Analytics ${ }^{[51]}$.

$\mathrm{AE}$ journals were originally grouped within a generic Engineering category in the $1997 \mathrm{JCR}$ and then subsequently re-categorized to a specific AE category in the 2000 JCR (see search information in Appendix A). Nine journals were grouped in the 2000 JCR AE journal category, which expanded to 14 reported journals starting with the $2015 \mathrm{JCR}$. However, The Journal of the Korean Society for Applied Biological Chemistry was listed by mistake due to an unknown error in both the 2016 and 2017 JCR (Hubbard, S. 2018. Personal communication. Content Team Lead, JCR, Philadephia, PA: Clarivate Analytics). Thus the analyses performed for this study is limited to the 13 journals that were correctly indexed in the $2017 \mathrm{JCR}$ (but versions of selected tables and figures are provided in Appendix B that include data for The Journal of the Korean Society for Applied Biological Chemistry).

A curious mix of comprehensive and "specialty topic" journals have been represented in the JCR AE (and WoS CC AE) category since its inception in 2000. Specialty topic journals are defined here as being focused on a more narrow set of research topics that do not provide a forum for the broad range of topics published in comprehensive agricultural engineering journals, such as described for the journals Industrial Crops and Products ${ }^{[56]}$ and Paddy Water and Environment ${ }^{[57]}$. At present, the 13 journals in the 2017 JCR agricultural engineering journal category are generally split between comprehensive AE journals and specialty topic journals. A total of 13 metrics including the JIF are reported in the JCR for each journal in the $\mathrm{AE}$ category and the journals included in the other 235 JCR categories.

Hall and Olsen ${ }^{[58]}$ compiled 17 chapters of material focused on the influence and application of AE literature at that time. Those 17 chapters included an overview of the types of literature published by $\mathrm{ASAE}^{[59]}$, and the journals or other literature that served as the primary publication outlets and sources of citations 
for scientists conducting $\mathrm{AE}$ related research ${ }^{[60]}$. Reviews of $\mathrm{AE}$ journals have been recently reported in Chinese ${ }^{[61,62]}$. However, no known studies have since been published in English that focus on the characteristics and impacts of key AE engineering journals.

Thus the goal of this study is to review the structure and impacts of the 13 journals, and the utilization of those journals in the research community, that are currently indexed in the 2017 JCR and WoS CC AE categories (and reflect 2016 citation data). Specifically, the objectives are: (1) to describe the characteristics of the 13 journals based on type of publisher, focus of the journal (comprehensive versus specialty), research topics covered in each journal, total annual articles published and other factors; (2) compare the relative impact of the 13 journals as a function of 2017 JCR JIF, 5-year JIF and total cites metrics, as well as long-term JIF trends; (3) describe long-term publication trends among the 13 journals as well as national, institutional publication and other trends based on data reported in the WoS CC AE category; and (4) discuss the need for possible revisions to the current JCR and WoS $\mathrm{CC}$ AE categories to more accurately reflect the impact of comprehensive AE engineering journals. The 2018 JCR, which reports 2017 citation data, was released during the final stages of the preparation of this study. JIF data based on the 2018 JCR AE journals category are reported in Appendix C.

\section{Description and key metrics for JCR agricultural engineering journals}

\subsection{Characteristics of JCR AE category journals}

The 13 journals indexed in the JCR AE category are listed in Table 1 per several criteria including classification, JIF rank, journal name, sponsoring society (if applicable), publisher, publication frequency and publication model (traditional versus open access). The journals are partitioned in Table 1 on the basis of being classified as specialty journals versus comprehensive journals and are further ordered within the two main subsections of the table as a function of $2016 \mathrm{JIF}$ values (see Section 2.2 for specific JIF values). The JCR abbreviated names (Table 1) are used in the remainder of the discussion when referencing one or more of the 13 specific journals.

Table 1 Classifications, JIF rank, journal titles, professional society, publisher and publication characteristics for the 13 journals indexed in the 2017 JCR Agricultural Engineering Category ${ }^{\text {a,b }}$

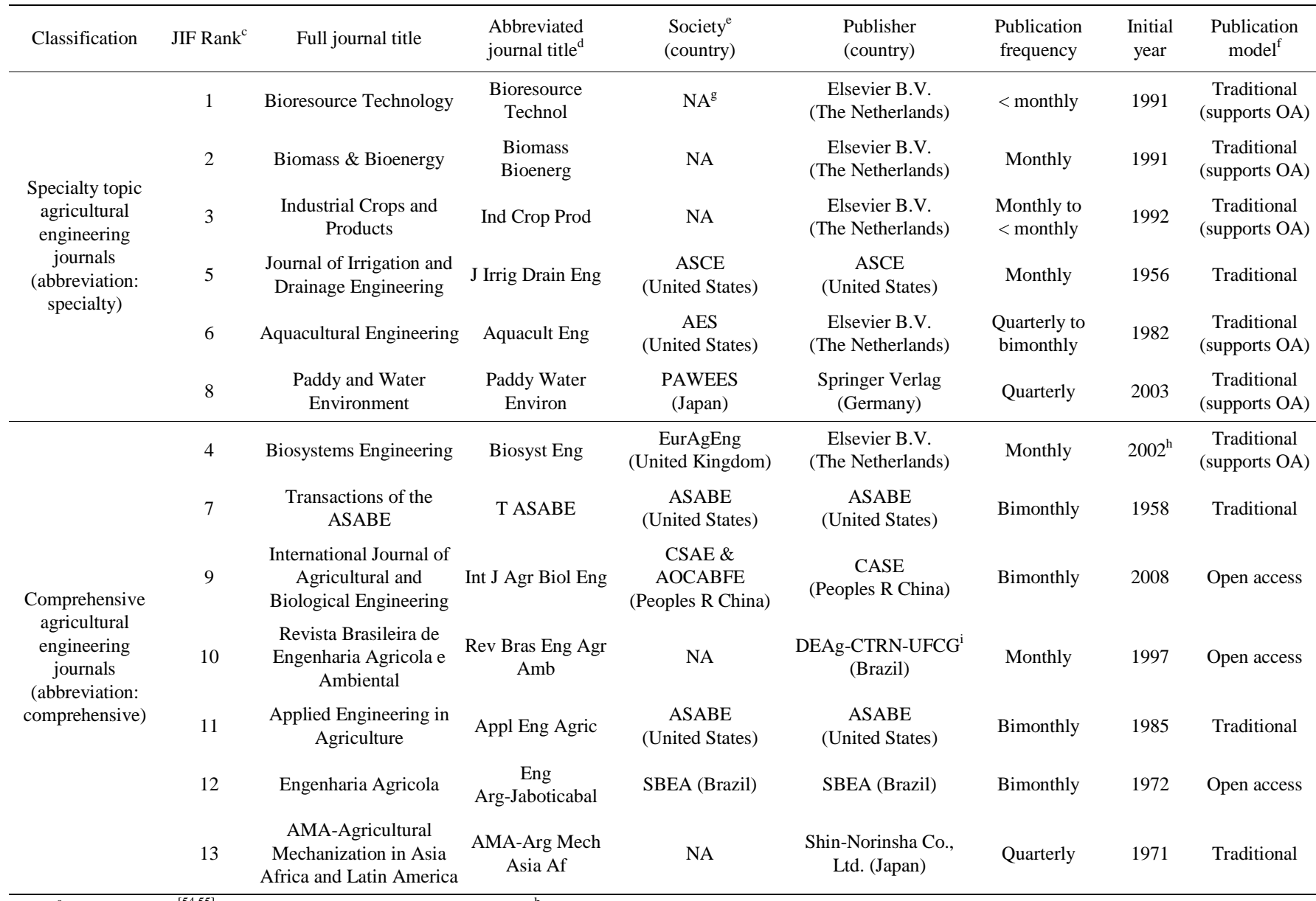

Note: ${ }^{\mathrm{a}}$ The $2017 \mathrm{JCR}^{[54,55]}$ reports citation data recorded in $2016 .{ }^{\mathrm{b}}$ The Journal of the Korean Society for Applied Biological Chemistry is also indexed in the 2015 and 2016 JCR Agricultural Category. However, this occurred due to an unknown error (Hubbard, S. Personal communication. Content Team Lead, JCR, Clarivate Analytics, Philadephia, PA). Thus no further reporting of data for the journal is included in this study. ${ }^{\mathrm{c}} \mathrm{JIF}$ rank is reported in the $2017 \mathrm{JCR}$ as listed in Table 5 in section 2.2. ${ }^{\mathrm{d}}$ Abbreviated journal title names as reported in the JCR Agricultural Engineering category. ${ }^{\mathrm{e}}$ Definitions of society abbreviations: AES = Aquacultural Engineering Society (https://www.aesweb.org/); ASCE = American Society of Civil Engineering (https://www.asce.org/); PAWEES = International Society of Paddy and Water Environment Engineering (http://pawees.net/); EurAgEng = European Society for Agricultural Engineers (https://www.eurageng.eu/); CSAE = Chinese Society of Agricultural Engineering (http://www.csae.org.cn/); AOCABFE = Association of Overseas Chinese Agricultural, Biological, and Food Engineers (http://aocabfe.com/); ASABE = American Society of Agricultural and Biological Engineers (http://www.asabe. org/); SBEA = Brazilian Association of Agricultural Engineering (http://www.sea.org.br/). ${ }^{\mathrm{f}}$ Traditional = no articles are published open access; Traditional (supports OA) = open access articles are possible for a fee; open access $=$ all of the articles are published open access (also requires publication fees). ${ }^{\mathrm{g}} \mathrm{NA}=$ not applicable. ${ }^{\mathrm{h}}$ Biosyst Eng was previously published as the $J$ Agr Eng Res between 1956 and 2001 ${ }^{[32]}$. ${ }^{\mathrm{i}}$ DEAg-CTRN-UFCG = Departamento de Engenharia Agrícola, Centro de Tecnologia e Recursos Naturais, Universidade Federal de Campina Grande (http://www.scielo.br/revistas/rbeaa/iaboutj.htm). 
The journals with the greatest longevity are J Irrig Drain Eng, $T A S A B E$ and Biosyst Eng, which were first published in the late 1950s (Table 1); Biosyst Eng was originally J Agr Eng Res (Table 1). The other journals were initiated anywhere between the early 1970s and the first decade of the 21 st century. Nine of the journals are sponsored by various professional societies such as ASABE and EurAgEng. Six of the journals are published by either Elsevier B. V. or Springer Verlag, which are dominant for-profit publishers ${ }^{[63]}$, including the journals sponsored by the Aquacultural Engineering Society (AES), International Society of Paddy and Water Environment Engineering (PAWEES) and EurAgEng (Table 1). Both Rev Bras Eng Agr Amb and Eng Arg-Jaboticabal originally published accepted studies predominantly in Portuguese. However, Rev Bras Eng Agr Amb converted to exclusively English articles in the 2016 publication year ${ }^{[64]}$ and Eng Arg-Jaboticabal has essentially made the same conversion, although the instructions to authors indicate that articles written in Portuguese and Spanish are also accepted ${ }^{[65]}$.

The majority of the journals publish either exclusively in a traditional mode, which does not support open access publishing, or publish predominantly in a traditional mode but also provide options for publishing articles in open access formats ("Traditional (supports OA)" in Table 1). The fees for publishing open access articles in the Elsevier journals (Table 1) range from $\$ 2750$ for Biosyst Eng ${ }^{[66]}$ to $\$ 3600$ for Aquacult $E n g^{[67]}$. Open access articles published in Springer journals are charged a standard fee of $\$ 3000^{[68]}$. In contrast, all articles are published in open access format in Int J Agr Biol Eng, Rev Bras Eng Agr Amb and Eng Arg-Jaboticaba for varying submission and/or publication fees as described on the respective journal websites, which are typically considerably less than those charged by Elsevier and Springer. All of the journals, which publish partially or totally in open access mode, publish open access articles based on Creative Commons licensing agreements ${ }^{[69]}$. In general, the JCR AE category publication trends confirm the growing influence of disseminating scientific research via open access publishing formats.

The publication frequency (Table 2) ranges from quarterly (Paddy Water Environ and AMA-Arg Mech Asia Af) to multiple times per month (Bioresource Techno; i.e., "< monthly"). Ind Crop Prod and Aquacult Eng have manifested some irregular publication frequency patterns in recent years. Considerable year-to-year fluctuation can also occur in the number of articles published for a given journal as evidenced by the total articles published in 2015 versus 2016 (e.g., Ind Crop Prod and T ASABE). The total articles published on an annual basis varies dramatically across the 13 journals as shown by 2015 and 2016 WoS Core Collection data (Table 2). The lowest level of published articles per year occurred for Paddy Water Environ, AMA-Arg Mech Asia Af and Aquacult Eng, which is consistent with the lower frequency of published issues for those three journals. At the opposite extreme, the total articles published per year in Bioresource Technol and Ind Crop Prod are roughly factors of 30 and 15 greater as compared to the three journals with the lowest publication totals. The top three journals (Bioresource Technol, Ind Crop Prod and Biomass Bioenerg) comprised over $65 \%$ of the total publications in both 2015 and 2016, revealing that the scientific community intersecting with those journals is relatively huge compared to traditional AE disciplines. This is further confirmed by the data in Table 2, which indicates that the seven comprehensive AE journals
(Table 1) represent $21 \%$ to $25 \%$ of the total JCR AE category publications in 2015 and 2016.

Strong contrasting topical differences between the comprehensive AE journals (Table 1) and the specialty journals can also be discerned between Tables 3 and 4 . Table 3 presents broad subdisciplines and corresponding example research topics, that are typically within the domain of overall material that could be published in a given issue of a comprehensive $\mathrm{AE}$ journal ${ }^{[33]}$. Some overlap may occur in research focus between the broad subdisciplines listed in Table 3. However, the majority of research that occurs within each broad subdiscipline occurs independently of research conducted in the other subdisciplines. The exact research topics that are of primary interest varies some between the different comprehensive journals (Table 1). This is especially true of AMA-Arg Mech Asia Af, which publishes research focused mainly on agricultural machinery use in developing regions and thus could be viewed as a specialty journal. However, there is no other logical JCR category that AMA-Arg Mech Asia Af could be slotted in. Overall, the comprehensive journals are characterized by the types of unique expansive research realms listed in Table 3.

Table 2 Total number of articles published in each of the 13 journals indexed in the JCR Agricultural Engineering category for 2015 and $2016^{\mathrm{a}}$

\begin{tabular}{lcccc}
\hline \multirow{2}{*}{ JCR journal title } & $\begin{array}{c}\text { Total } \\
\text { articles }\end{array}$ & $\begin{array}{c}\text { Proportion } \\
\text { /\% }\end{array}$ & $\begin{array}{c}\text { Total } \\
\text { articles }\end{array}$ & $\begin{array}{c}\text { Proportion } \\
\text { /\% }\end{array}$ \\
\cline { 2 - 5 } & \multicolumn{2}{c}{2015} & \multicolumn{2}{c}{2016} \\
\hline Bioresource Technol & 1537 & 37.7 & 1615 & 40.12 \\
Ind Crop Prod & 937 & 23.0 & 713 & 17.71 \\
Biomass Bioenerg & 356 & 8.7 & 317 & 7.88 \\
Biosyst Eng & 164 & 4.0 & 193 & 4.80 \\
Aquacult Eng & 52 & 1.3 & 45 & 1.12 \\
J Irrig Drain Eng & 158 & 3.9 & 176 & 4.37 \\
Int J Agr Biol Eng & 106 & 2.6 & 133 & 3.30 \\
T ASABE & 154 & 3.8 & 203 & 5.04 \\
Paddy Water Environ & 51 & 1.3 & 47 & 1.17 \\
Rev Bras Eng Agr Amb & 180 & 4.4 & 180 & 4.47 \\
Appl Eng Agric & 95 & 2.3 & 104 & 2.58 \\
Eng Agr-Jaboticabal & 113 & 2.8 & 125 & 3.11 \\
AMA-Agr Mech Asia Af & 53 & 1.3 & 63 & 1.57 \\
Total & 4078 & 100 & 4025 & 100 \\
\hline Note: Repoted & & & & \\
\hline
\end{tabular}

Note: ${ }^{a}$ Reported in the WoS CC AE data ${ }^{[51]}$.

Table 4 presents the specific research topics that are covered in the seven specialty journals. The topical coverage provided by each of the seven specialty journals is very narrow as compared to the broad subdisciplines covered by most of the comprehensive $\mathrm{AE}$ journals. In addition, these specialty journals are categorized in at least one other JCR category (Table 4), indicating that these journals are of primary interest to other distinct scientific disciplines. However, Biosyst Eng is the only comprehensive AE journals (Table 1) categorized in another JCR category (Agriculture, Multidiscplinary), for reasons that are not clear relative to the other comprehensive AE journals. The specific research topics and additional categorizations of the specialty journals underscore the distinct differences of those journals versus the comprehensive $\mathrm{AE}$ journals, which is addressed in more detail below. 
Table 3 Example broad subdisciplines and research topics represented in comprehensive agricultural engineering journals ${ }^{\mathrm{a}}$

Broad subdisciplines

Applied Science, Engineering and Technology

Animal, Plant and Facility Systems

Power and Machinery Systems

Natural Resources and Environmental Systems

Information Technology, Sensors and Control Systems

Biosystems, Biological and Ecological Engineering

Renewable Energy and Material Systems

Agro-product and Food Processing Systems

Structures and Bio-environmental Engineering

Safety, Health and Ergonomics
Example research topics

Applied physics, biomaterial sciences, biology, biological engineering fundamentals, bioprocessing, biological kinetics, biosystem modeling

Structures for animal housing, plant production, commodities storage, environmental air quality, environment of animal and plant structures, plant growth chambers, greenhouses, high tunnels, manure management

Design and manufacturing, mechanization and automation, man-machine system interaction, precision agriculture and emerging technologies, tractor \& implement hydraulics, mechanical aspects of harvesting

Design and installation of structural conservation practices, irrigation systems, applications of ecohydrological models, environmental impacts of cropping and management systems, applications of GIS and RS, water quality

Artificial intelligence, advanced sensing technology, biosensors and system control, computer aided systems, GIS, GPS, RS agricultural applications

Biorenewables production and processing, convert bio-based resources to food and fuel, biosensors, water quality, environmental impacts of the bioeconomy

Innovative energy sources, renewable energy technologies, biomass production, handling, utilization, energy efficiency and conservation

Post-harvest handling and storage, food and biological processing engineering, imaging and sensing technology, food safety and security, food technology

Environmental control of animal and plant structures, imposed loads on structures, materials of construction; agricultural waste management

All engineering aspects of ergonomic human safety and health for users of equipment systems and facilities in agriculture

Note: ${ }^{a}$ See Table 1 for additional details regarding the specific comprehensive agricultural engineering journals.

\subsection{Definitions of JCR Total Cites, JIF and 5-Year JIF metrics}

As noted previously, 13 different metrics are reported for each journal included in the $\mathrm{JCR}^{[40]}$. Three key metrics from that overall set are analyzed here for the 13 journals in the JCR AE category: total cites, JIF and 5-year JIF.

The JCR total cites (TC) metric is defined in documentation for the database as: "The total number of times that a journal has been cited by all journals included in the database in the JCR year" ${ }^{\text {"[70] }}$. This is a straight forward metric that is calculated on the basis of citations in a given year to all of the articles that have been published in the respective journal for all of the years that the journal has been indexed in the WoS. The TC for a given journal in a given year can be influenced by a number of factors and is especially affected by the total number of articles that are typically published on an annual basis in the specific journal. The TC metric can show the degree that the journal is used and valued, and the role and status in scientific communication.

Table 4 Primary research areas covered by specialty topic journals ${ }^{\mathrm{a}}$ in the JCR Agricultural Engineering category

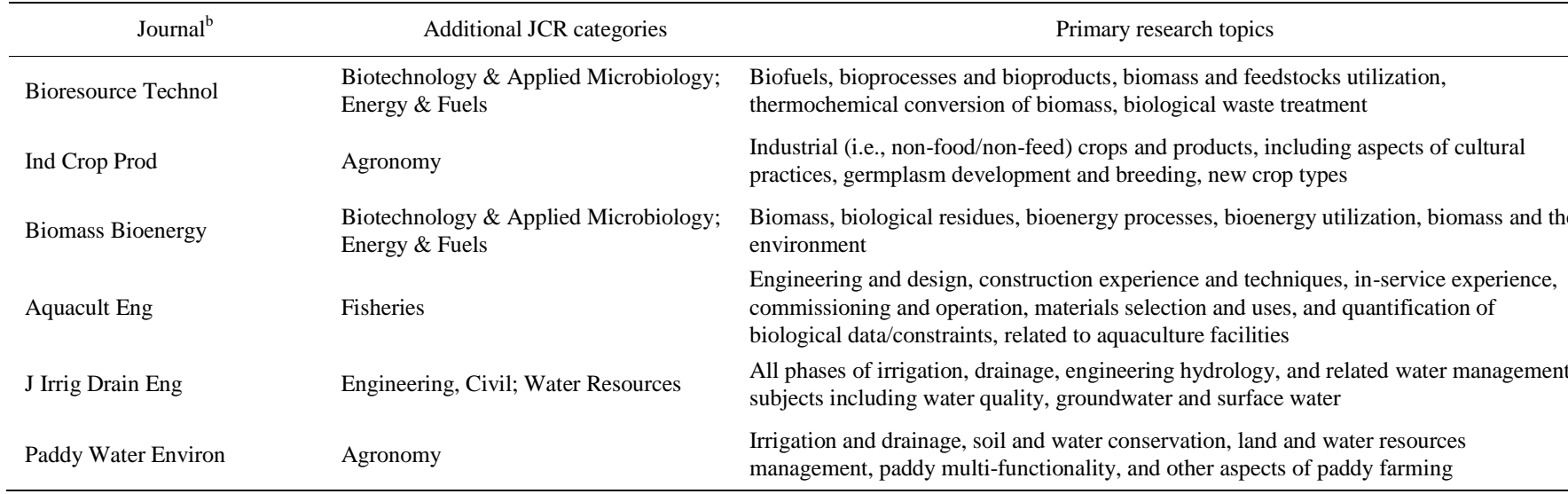

Note: ${ }^{a}$ See Table 1 for additional details about each journal. ${ }^{\mathrm{b}}$ Sources: Bioresource Technol (https://www.journals.elsevier.com/bioresource-technology/); Ind Crop Prod (https://www.journals.elsevier.com/industrial-crops-and-products); Biomass Bioenergy (https://www.journals. elsevier.com/biomass-and-bioenergy); Aquacult Eng (https://www.journals.elsevier.com/aquacultural-engineering); J Irrig Drain Eng (https://ascelibrary.org/page/jidedh/editorialboard); Paddy Water Environ (https://link.springer. com/journal/10333).

The JIF is determined for a journal in a specific year by: (1) determining the total number of citations received by articles published in the journal during the preceding two years (during the year that the JIF is calculated for), (2) summing the total number of articles that were published in the journal during the preceding two years, and (3) finally dividing the total citations by the total number of articles ${ }^{[[40,52,71]}$. For example, a JIF for a hypothetical journal would be calculated as follows for the year 2016:

JIF_2016 = (Citations_(2014+2015))/(Publications_(2014+2015)) where, JIF_2016 = the JIF calculated for the journal in 2016, Citations_(2014+2015) are the total number of citations received by articles published in the journal during 2014 and 2015, and Publications_(2014+2015) are the total articles that were published in the journal during 2014 and 2015. As noted previously, the JCR data published each year includes JIF metrics only for journals that are indexed in the WoS SCIE and/or SSCI databases. However, citations recorded for a specific journal in either of those two databases can be accrued from any of the five WoS journal or proceedings index databases; i.e,, SCIE, SSCI, ACHI, CPCI-S or 
CPCI-SSH ${ }^{[52]}$. It can be seen that the citation peak period, citation frequency and the total published articles are the three main factors that influence the JIF, and those three factors can be affected by numerous sub-factors.

The 5-year Journal Impact Factor (5-year JIF) is calculated in the same way that the standard JIF is calculated except that a five-year time period is used rather than a two-year period ${ }^{[40,72]}$. Thus the 5-year JIF is a measure of impact for a given journal that is calculated by: dividing the total citations to articles published during the preceding five years in the journal by the total number of articles published in that journal during the previous five years. The 5-year JIF can potentially provide more insight into broader long-term citation patterns and can also mitigate, to some extent, extreme JIF fluctuations caused by one or more very highly cited articles; e.g., see discussion about such fluctuations provided by Liu et al. ${ }^{[73]}$ However, 5-year JIF values are not reported for journals that have been indexed in the JCR for less than five years.

\subsection{JCR AE category total cites, JIF and 5-year JIF metrics}

Table 5 shows the 2016 total cites, JIF and 5-year JIFs reported for the 13 journals in the $2017 \mathrm{JCR}$ AE category (Table 1). The journals are ranked in Table 5 on the basis of the highest JIF (Bioresource Technol; 5.651) to the lowest JIF (AMA-Agr Mech Asia $A f ; 0.118)$ values. The other metrics generally follow the same ranking as the JIF values although there are notable exceptions; e.g., the strong 5-year JIF for Aquacult Eng and the relatively high level of total cites reported for T ASABE. The 5 -year JIF is higher than the standard JIF for the majority of the 13 journals although the reverse relationship is evident for $J$ Irrig Drain Eng and AMA-Agr Mech Asia Af, which indicates an increasing level of citations during 2014 and 2015 for both journals. There is no 5-year JIF reported for Int J Agr Biol Eng because the journal was indexed for the first time during 2013 in the WoS CC (thus lacking sufficient data).

Table 5 Total cites, JIF and 5-year JIF values reported for the 13 JCR Agricultural Engineering category journals for citation data recorded in $2016^{\mathrm{a}}$

\begin{tabular}{lcccc}
\hline \multicolumn{1}{c}{ Journal title } & Total cites & JIF & 5-Year JIF & Classification \\
\hline Bioresource Technol & 93612 & 5.651 & 6.102 & specialty \\
Biomass Bioenerg & 18312 & 3.219 & 4.186 & specialty \\
Ind Crop Prod & 15116 & 3.181 & 3.577 & specialty \\
Biosyst Eng & 4495 & 2.044 & 2.238 & comprehensive \\
J Irrig Drain Eng & 3434 & 1.983 & 1.842 & specialty \\
Aquacult Eng & 1917 & 1.559 & 2.004 & specialty \\
T ASABE & 8412 & 0.975 & 1.264 & comprehensive \\
Paddy Water Environ & 609 & 0.916 & 1.218 & specialty \\
Int J Agr Biol Eng & 503 & 0.835 & - & comprehensive \\
Rev Bras Eng Agr Amb & 1311 & 0.608 & 0.78 & comprehensive \\
Appl Eng Agric & 1590 & 0.505 & 0.667 & comprehensive \\
Eng Agr-Jaboticabal & 686 & 0.353 & 0.59 & comprehensive \\
AMA-Agr Mech Asia Af & 106 & 0.118 & 0.087 & comprehensive \\
\hline
\end{tabular}

Note: ${ }^{a} 2016$ statistics are reported in the 2017 JCR published by Clarivate Analytics ${ }^{[54,55]}$.

The rankings presented in Table 5 reveal the dominance of both specialty journals and journals published by Elsevier B.V. (Table 1), among the 13 journals included in the current JCR AE category. Specialty journals occupy five of the top six ranked journals while five of the comprehensive AE journals are ranked among the bottom seven journals, including the bottom four journals. The strong metrics for the top two journals, Bioresource Technol and Biomass Bioenerg, confirm the intense interest across a sizable subset of the scientific community regarding biofuels, bioenergy processes and related topics. The $2016 \mathrm{JIF}$ reported for Ind Crop Prod was just slightly below Biomass Bioenerg (3.181 versus 3.219), but distinctly stronger total cites and 5-year JIF metrics were reported for Biomass Bioenerg in 2016. The relative strengths of the JIFs and other metrics for Ind Crop Prod, J Irrig Drain Eng and Aquacult Eng reveal that the specific topics published in those three specialty journals are of strong interest to important subsets of the overall scientific community.

Five of the top six ranked journals shown in Table 5 were published by Elsevier B.V., with the lone exception being J Irrig Drain Eng which is published by the American Society of Civil Engineers (Table 1). This is likely due primarily to the topical coverage of the five journals, although it may also reveal that there is wider accessibility and/or familiarity across the scientific community regarding Elsevier B.V. journals, even though none of the journals publish in full open access format. Biosyst Eng is the top ranked comprehensive agricultural engineering journal (number 4 in Table 5) and is one of the five journals published by Elsevier B.V. (Table 1). In general, the JIF and other metrics shown in Table 5 underscore that Biosyst Eng is a very important journal within the $\mathrm{AE}$ research domain which is further confirmed by global citation trends discussed in Section 3.2.

$T A S A B E$ is the second highest ranked comprehensive $\mathrm{AE}$ journal in terms of JIF value (0.975) and resides at the bottom of the upper tier of journals (Table 5). However, T ASABE attracts a relatively high annual rate of citations (8412 in 2016; Table 5) due in large part to a subset of very highly cited articles ${ }^{[74-84]}$. The JIF values for Int J Agr Biol Eng, Rev Bras Eng Agr Amb, Appl Eng Agric and Eng Agr-Jaboticabal are 0.835, 0.608, 0.505 and 0.353, with AMA-Agr Mech Asia Af anchoring the bottom of Table 5 $(\mathrm{JIF}=0.118)$. Int J Agr Biol Eng started in 2008 with a quarterly publication cycle and increased to a bimonthly publication rate in 2014 , reflecting an increasing number of submissions and gradually strengthening role in the international research community. Rev Bras Eng Agr Amb and Eng Agr-Jaboticabal are primarily regional journals at present, as reflected by the fact that the vast majority of articles that have been published in both journals to date were written by Brazilian authors (see Section 3.2). However, the conversions to manuscripts written in English for both journals may result in increasing international submissions in the future. Appl Eng Agric could be considered a niche journal designed by ASABE to complement $T A S A B E$ with more applied focused articles, although the distinctions in article types between the two journals are not always clear. AMA-Agr Mech Asia Af is clearly a very narrow niche journal focused almost exclusively on agricultural machinery research in developing nation contexts, resulting in a relatively low publication rate and very low citation metrics.

Paddy Water Environ is the other journal listed in the bottom half of Table 5, which is published by Springer Verlag (Table 1) and received a JIF value of 0.916 in 2016 . The relatively low JIF value for Paddy Water Environ, which is classified as a specialty journal (Tables 1 and 5), suggests that the respective range of published research topics are quite narrow (in spite of the enormous levels of rice production that occur worldwide). However, there could be other factors affecting the exposure and citation rates to articles published in Paddy Water Environ including journal 
management and overall exposure of the journal among the wider scientific community.

\subsection{Long-term JIF trends for JCR AE category journals}

Figure 1 shows long-term JIF trends for the 13 journals included in the JCR AE category starting at the year 2000. The plotted JIFs for some of the journals span shorter time periods due to initial indexing of those journals in the JCR in more recent years; e.g., Int J Agr Biol Eng in 2015. The Biosyst Eng JIF was reported for the first time in 2003 and was previously reported in the JCR using the original $J$ Agr Eng Res name (JIF values were reported for both Biosyst Eng and J Agr Eng Res in the 2003 JCR). Minor name changes also occurred for $T A S A B E$ in 2006 (previously T ASAE through 2005) and J Irrig Drain Eng in 2013 (previously J Irrig Drain Eng ASCE through 2012).
The initial JIF values for all of the JCR Agricultural Engineering category journals shown in Figure 1 were less than 1.0 and some were less than 0.5 . Relatively strong increasing trends in JIF values can be seen for several of the journals although there is also considerable year-to-year variability, reflecting annual shifts in the number of published articles, total citations to a journal's articles, etc. The JIF values for Bioresource Technol and Biomass Bioenerg have increased by factors of 6 to 8 from the initial year of 2000 to 2016 (Figure 1). Relatively strong trends in increasing JIF values are also shown for Ind Crop Prod, Biosyst Eng (J Agr Eng Res) and Aquacult Eng, which increased by respective factors of roughly 2.5 to 4.5 times between 2000 and 2016. A range of long-term JIF trends are reflected in plots of JIF values for the other journals (Figure 1).

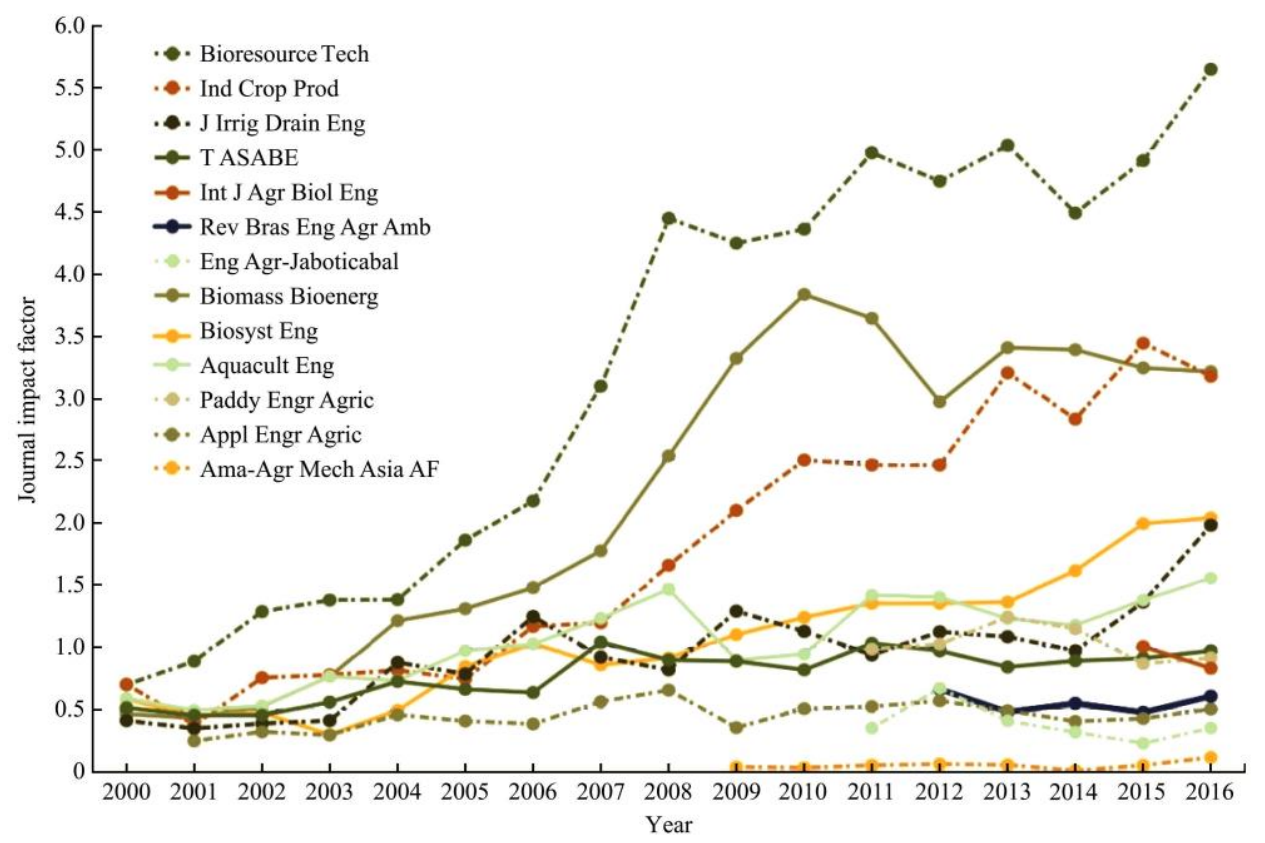

Figure 1 Long-term trends in JIF values for the 13 journals indexed in the JCR Agricultural Engineering category ${ }^{[54]}$

The general strong increasing JIF value trends shown for Bioresource Technol and Biomass Bioenerg (Figure 1) confirm the rapid rising research focus on bioenergy related topics that has occurred worldwide in the past decade. However, the annual JIF values for Biomass Bioenerg have declined by about 0.6 by 2016, from the peak of roughly 3.8 in 2010, for reasons that are not immediately clear. The JIF values for Ind Crop Prod have generally progressively increased from 2000 to 2016, which point to growing interest in the types of industrial crop related topics covered by the journal. The JIF values for Biosyst Eng are the only ones among the comprehensive AE journals that display a gradual upward trend over the past decade. In contrast, the JIF values for TASABE and Appl Eng Agric have essentially remained static during the decadal period between 2007 and 2016 (Figure 1).

\section{Global Research Characteristics of the WoS CC AE category}

Members of agricultural engineering societies, university departments focused on agricultural, biological and/or biosystems engineering, and other scientists who are affiliated with those fields in various ways publish research in a broad range of scientific journals that encompasses far more journals than just those indexed in the JCR and WoS CC AE categories. For example, scientists associated with the Iowa State University Agricultural and
Biosystems Engineering Department published over 200 articles in WoS CC indexed journals during 2014 to 2016, of which only $22 \%$ were published among the 13 AE journals (Helmers M. Personal communication. Agricultural and Biosystems Engineering Dept., Iowa State Univ., 2017). Thus the publication trends associated with the JCR and WoS CC AE category journals can only provide a partial view of the overall publication trends occurring within the AE realm. And a subset of the authors publishing in the 13 journals represent other disciplines that are not directly affiliated with the AE field and related disciplines. However, these trends do provide important insights regarding publication developments occurring among the specialty and comprehensive JCR and WoS $\mathrm{CC}$ AE category journals. The results reported in Section 3 were obtained from the journal data indexed in the WoS CC AE category.

\subsection{Total articles}

Figure 2 shows the trends in total articles published among the journals indexed in the WoS CC AE category during 2006 to 2016 using two different search methods available in the Advanced Search options: (1) Web of Science Category (WC), and (2) Publication Names (SO). The WC method returns all of the articles indexed in the $\mathrm{CC}$ AE category for each journal in a given year. The SO option also returns the total articles indexed for selected journals in a specific year, which requires including the 
name of each journal in the SO search for the given search year. The two methods result in different totals for some years due to various issues, some of which are described in more detail in Appendix D.

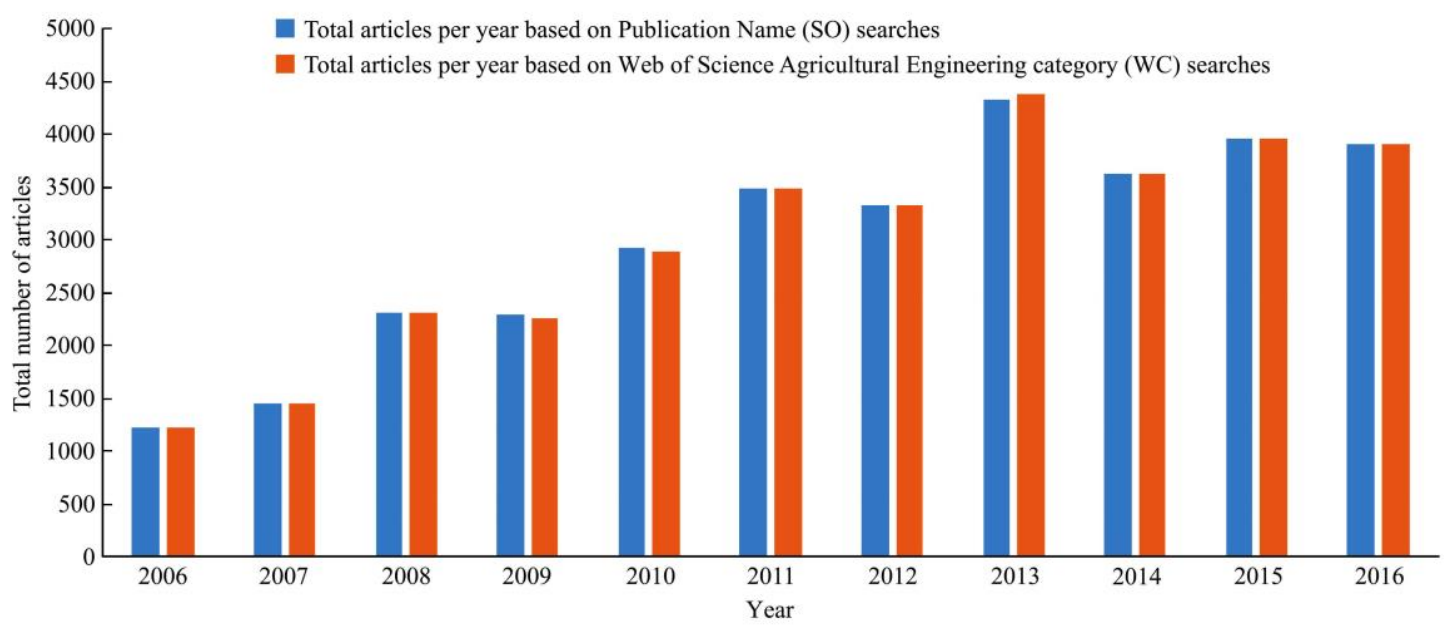

Figure 2 Total articles indexed in the WoS Core Collection Agricultural Engineering category using two different types of search structures as described in Appendix D

The total articles published in the WoS CC AE category journals (Figure 2) generally increased between 2006 and 2013, followed by a slight decline during the next three years. The exact fluctuations during those time periods based on the SO/WC searches were $1222 / 1225$ to $4331 / 4389$ articles from 2006 to 2013, which then declined to $3914 / 3914$ articles in 2016. The general increase in total articles published in the category over the 11-year time period was due in part to additional journals that were indexed in the WoS CC AE category in 2007 or later, although this was offset some by journals that were dropped from the category after being indexed for one to four years. However, large increases in the number of articles published in Bioresource Technol, Biomass Bioenerg and Ind Crop Prod during the 11-year period was by far the greatest factor in the overall trend of increased articles. The number of articles published in Bioresource Technol, Biomass Bioenerg and Ind Crop Prod increased from respective low total articles of 337 (2006), 95 (2007) and 78 (2007) to respective high total articles of 1987 (2013), 570 (2011) and 937 (2015). In general, only minor shifts in total published articles occurred for the other JCR AE journals during the 11-year period. However, exceptions occurred for the J Irrig Drain Eng, Eng Agr-Jaboticabal and the Int J Agr Biol Eng, which increased from 105 (2006) to 176 (2016), 77 (2008) to 125 (2016) and 50 (2013) to 133 (2016) total articles, respectively.

\subsection{Country and regional influences}

Table 6 shows the top 20 countries represented by the authors who published studies in journals that were indexed in the WoS CC AE category in 2006 versus 2016. In 2006, authors affiliated with United States institutions contributed over $37 \%$ of the articles that were published in the WoS CC AE category, which was equivalent to the next six countries (India, Canada, Spain, Peoples R China, Japan and Turkey) combined. However, dramatic shifts occurred in the contributing countries by 2016, with authors located in the Peoples R China contributing over articles $28 \%$ of the overall articles. This was roughly equal to the total articles contributed by the combined authors from the United States and Brazil in 2016 (Table 6), which were ranked second and third, respectively. The surge in published articles by Chinese authors in the WoS CC AE category mirrors similar increasing publication trends by Chinese institutions in other scientific disciplines ${ }^{[86-92]}$. In general, articles contributed by authors located in the countries listed in Table 6 for
2006 greatly increased by 2016 , although the order of ranking shifted considerably over that ten-year time period. Of particular note was the increase in published articles from Brazilian authors, which was likely primarily due to the indexing of the two Brazilian journals to the WoS CC and the JCR (Table 1) between 2006 and 2016.

Further investigation of contributing authors by country was conducted for all of the comprehensive agricultural engineering journals listed in Table 1, except for AMA-Arg Mech Asia Af due to the more narrow topical focus of that journal as previously discussed. Figure 3 shows the distribution of author affiliations of the top 25 countries or regions who published in Biosyst Eng during 2002 to 2016, which has manifested the strongest JIF trends among the comprehensive agricultural engineering journals during the past decade (Figure 1). Authors from the United States were the top contributors to Biosyst Eng during the 2002 to 2016, having written slightly over $14 \%$ of the studies published during that time period. The percentage contributions of the next 10 ranked countries/regions ranged from $8.8 \%$ (Spain) to $4.4 \%$ (the Netherlands), with a gradual decline in percentage contributions from the remaining 14 countries. However, the total articles contributed from European countries account for 54\% when European authors are viewed as a combined contributing block. In general, the data in Figure 3 reveals that the locations of authors who contribute to Biosyst Eng are distributed across a wide range of countries and regions, indicating that the journal has established a strong worldwide influence.

The distribution of country/region authorship shows a distinctly different pattern for the other five comprehensive $\mathrm{AE}$ journals, all of which are dominated by articles contributed from the host country that the journal is published in (Table 7). The concentration of authorship represented by the respective host country ranged from $71.6 \%$ (China) for Int J Agr Biol Eng to 99.1\% (Brazil) for Rev Bras Eng Agr Amb during 2002 to 2016. The concentration patterns remained virtually identical through roughly the first one-third of 2018, except for an increasing concentration of authors from China for Int J Agr Biol Eng (Table 7). These concentration trends underscore that the five journals listed in Table 7 tend to serve more as specific regional publication outlets as compared to Biosyst Eng, especially for the two journals that are published in Brazil. However, these publication 
characteristics do not necessarily reflect overall global influence as

highly cited articles published in $T A S A B E$.

discussed in further detail in Section 3.3, especially regarding

Table 6 Top 20 countries/regions with authors who published studies in the 2006 and 2016 WoS CC AE Category

\begin{tabular}{|c|c|c|c|c|c|c|c|}
\hline \multicolumn{4}{|c|}{2006} & \multicolumn{4}{|c|}{2016} \\
\hline Rank & Countries/Regions & Amount & Proportion/\% & Rank & Countries/Regions & Amount & Proportion/\% \\
\hline 1 & United States & 457 & 37.4 & 1 & Peoples R China & 1132 & 28.1 \\
\hline 2 & India & 160 & 13.0 & 2 & United States & 669 & 16.5 \\
\hline 3 & Canada & 77 & 6.3 & 3 & Brazil & 474 & 11.8 \\
\hline 4 & Spain & 75 & 6.1 & 4 & India & 300 & 7.5 \\
\hline 5 & Peoples R China & 70 & 5.7 & 5 & South Korea & 225 & 6.3 \\
\hline 6 & Japan & 46 & 3.8 & 6 & Spain & 176 & 4.4 \\
\hline 7 & Turkey & 42 & 3.4 & 7 & Italy & 171 & 4.2 \\
\hline 8 & Sweden & 31 & 2.5 & 8 & Canada & 146 & 3.6 \\
\hline 9 & Italy & 30 & 2.5 & 9 & France & 126 & 3.1 \\
\hline 10 & Australia & 27 & 2.2 & 10 & Germany & 120 & 3.0 \\
\hline 12 & South Korea & 24 & 2.0 & 12 & Australia & 101 & 2.5 \\
\hline 13 & Brazil & 21 & 1.7 & 13 & Japan & 94 & 2.3 \\
\hline 14 & France & 20 & 1.6 & 14 & England & 73 & 1.8 \\
\hline 15 & Taiwan & 20 & 1.6 & 15 & Portugal & 67 & 1.7 \\
\hline 16 & Belgium & 19 & 1.6 & 16 & Netherlands & 62 & 1.5 \\
\hline 17 & Iran & 19 & 1.6 & 17 & Turkey & 60 & 1.5 \\
\hline 18 & Netherlands & 19 & 1.5 & 18 & Taiwan & 56 & 1.4 \\
\hline 19 & Germany & 18 & 1.4 & 19 & Malaysia & 53 & 1.3 \\
\hline 20 & Denmark/Thailand ${ }^{\mathrm{a}}$ & 17 & 1.4 & 20 & Belgium & 51 & 1.3 \\
\hline
\end{tabular}

Note: ${ }^{a}$ Denmark and Thailand were tied for the number 20 rank in 2006 with 17 articles each.

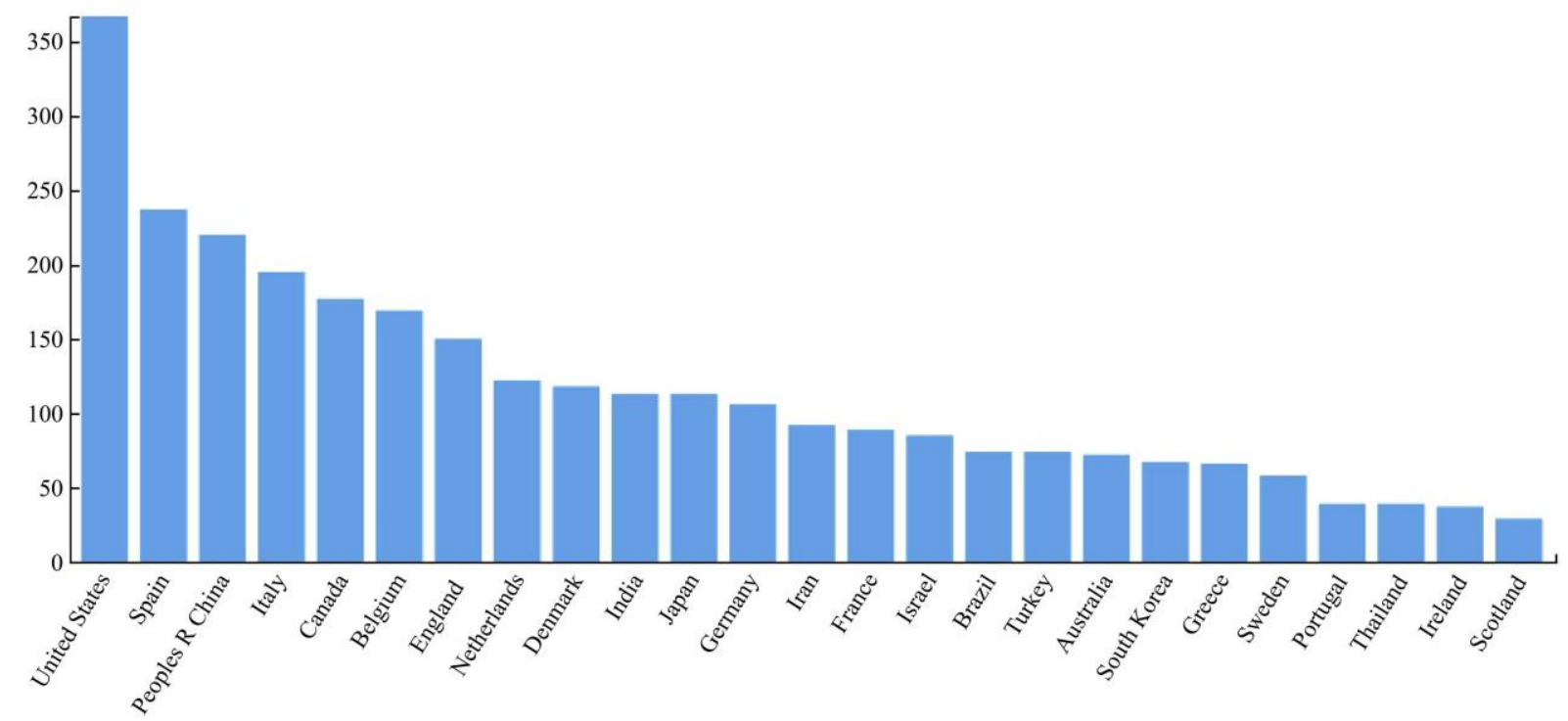

Figure 3 Distribution of countries represented in articles that were published in Biosystems Engineering during 2002 to 2016 as reported in the WoS CC AE category

Table 7 Concentration of authorship from the host country, where the respective journal is published in, for five of the comprehensive agricultural engineering journals

\begin{tabular}{|c|c|c|c|c|}
\hline \multirow{2}{*}{ Journal } & \multicolumn{2}{|c|}{2002 to 2016} & \multicolumn{2}{|c|}{2002 to $2018^{\mathrm{a}}$} \\
\hline & Country & $\%$ & Country & $\%$ \\
\hline Appl Eng Agric & United States & 76.0 & United States & 75.0 \\
\hline Eng Agr-Jaboticabal & Brazil & 96.6 & Brazil & 96.7 \\
\hline Int J Agr Biol Eng & China & 71.6 & China & 77.9 \\
\hline Rev Bras Eng Agr Amb & Brazil & 99.1 & Brazil & 99.0 \\
\hline T ASABE & United States & 76.1 & United States & 75.8 \\
\hline
\end{tabular}


Table 8 lists the top 20 contributing organizations/institutions regarding articles published in the Wos CC AE category in 2006 and 2016. The contribution patterns exhibited in Table 8 are reflective of the countries/region rankings in Table 6 , as shown by the dominance of U.S. agencies and universities in 2006 versus increased influence of counterpart Chinese and Brazilian research organizations in 2016. Several Indian institutes and universities were also represented in both 2006 and 2016.

Table 8 Top 20 organization/institution affiliations of authors who published studies in the 2006 and 2016 WoS CC AE Category ${ }^{\text {a }}$

\begin{tabular}{|c|c|c|c|c|c|c|c|}
\hline \multicolumn{4}{|c|}{2006} & \multicolumn{4}{|c|}{2016} \\
\hline Rank & Organization/Institution & Amount & Proportion \% & Rank & Organization/Institution & Amount & Proportion $\%$ \\
\hline 1 & United States Dept. of Agric. & 158 & 14.0 & 1 & Chinese Acad. of Sciences & 140 & 3.5 \\
\hline 2 & State Univ. System of Florida & 32 & 2.8 & 2 & United States Dept. of Agric. & 115 & 2.9 \\
\hline 3 & Indian Inst. of Technology & 31 & 2.7 & 3 & Council Sci. Ind. Res. CSIR India & 82 & 2.0 \\
\hline 3 & Univ. of Florida & 31 & 2.7 & 4 & Harbin Inst. of Technology & 63 & 1.6 \\
\hline 5 & Council Sci. Ind. Res. CSIR India & 25 & 2.2 & 5 & Universidade Estadual Paulista & 61 & 1.5 \\
\hline 5 & Texas A\&M Univ. System & 25 & 2.2 & 6 & China Agric. Univ. & 59 & 1.5 \\
\hline 7 & Univ. of California System & 22 & 1.9 & 6 & Univ. Chinese Academy of Sciences & 59 & 1.5 \\
\hline 7 & Kansas State Univ. & 21 & 1.9 & 8 & Zhejiang Univ. & 58 & 1.4 \\
\hline 9 & Texas A\&M Univ. College Station & 20 & 1.8 & 9 & Universidade De Sao Paulo & 46 & 1.1 \\
\hline 10 & Univ. of California Davis & 18 & 1.6 & 9 & Univ. of Tehran & 46 & 1.1 \\
\hline 11 & Indian Council of Agric. Res. & 16 & 1.4 & 12 & Indian Inst. of Technology & 44 & 1.1 \\
\hline 11 & Univ. of Illinois System & 16 & 1.4 & 12 & Univ. of Science Technology & 44 & 1.1 \\
\hline 11 & Univ. of Illinois Urbana Champaign & 16 & 1.4 & 14 & Univ. of California System & 40 & 1.0 \\
\hline 11 & Univ. of Nebraska System & 16 & 1.4 & 15 & Embrapa $^{\#}$ & 39 & 1.0 \\
\hline 11 & Univ. System of Georgia & 16 & 1.4 & 15 & South China Univ. of Technology & 39 & 1.0 \\
\hline 11 & Wageningen Univ. Res. & 16 & 1.4 & 17 & Northwest A F Univ. China & 37 & 0.9 \\
\hline 18 & Iowa State Univ. & 15 & 1.3 & 17 & Washington State Univ. & 37 & 0.9 \\
\hline 18 & Penn State Univ. & 15 & 1.3 & 18 & Indian Council of Agric. Res. & 35 & 0.9 \\
\hline 18 & Pennsylvania Comm. SHE & 15 & 1.3 & 18 & Univ. of Technology Sydney & 35 & 0.9 \\
\hline 18 & University of Nebraska & 15 & 1.3 & & & & \\
\hline
\end{tabular}

Note: ${ }^{a}$ Duplicate rank numbers reflect ties in reported amount of publications between institutions in 2006 or 2016.

\# The full name for Embrapa that is reported in the WoS Core Collection search is Empresa Brasileira de Pesquisa Agropecuaria.

\subsection{Characteristics of top cited articles}

A final assessment of the WoS CC AE category was performed by determining the distribution of topics among the all-time top 50 cited articles for the complete AE category (Table 9) and then for the journals defined as comprehensive AE journals (Table 10). The search structures used for determining the top 50 articles for each table (Appendix A) were constructed so that all of the articles that have been indexed for each of the journals in the WoS CC were included. This required including TASAE and $J$ Agr Eng Res, the original names for TASABE and Biosyst Eng, in the search structures to ensure that all of the older articles that were published in those two journals were considered within the analysis. A total of 58750 and 23086 articles were returned for the searches used to construct Tables 9 and 10, respectively.

The citations for the all-time top cited 50 articles for the 13 journals (Table 9) in the entire AE category ranged from 2980 for Mosier et al. (2005) ${ }^{[93]}$ to 537 for Allen et al. ${ }^{[94]}$ Studies published in Bioresource Technol were by far the most dominant, accounting for 34 of the overall top 50 cited articles. The remaining 16 studies were almost evenly split between Biomass Bioenerg and $T$ $A S A B E / T$ ASAE, with one article published in J Irrig Drain Eng. Nine of the top 10 cited articles, ranging between the 2980 citations for Mosier et al. ${ }^{[93]}$ and 1572 citations for Alvira et al. ${ }^{[95]}$, were published in Bioresource Technol. The only exception was Moriasi et al. ${ }^{[82]}$, which was published in $T$ ASABE and cited 2695 times. In general, bioenergy related topics were the dominant themes of the top cited articles although some exceptions occurred, especially for the top cited articles published in TASABE/T ASAE.
Table 9 Summary of the all-time top 50 cited journal articles that are indexed in the Web of Science Core Collection Agricultural Engineering category ${ }^{\mathrm{a}}$

\begin{tabular}{|c|c|c|}
\hline Journal & General topic ${ }^{\mathrm{b}}$ & Total articles \\
\hline \multirow{7}{*}{$\begin{array}{l}\text { Bioresource } \\
\text { Technol }\end{array}$} & Anaerobic digestion processes & 2 \\
\hline & Biodiesel production processes & 7 \\
\hline & Chemical or microbial processes & 7 \\
\hline & Other biofuel production processes & 4 \\
\hline & Processing of lignocellulosic biomass & 5 \\
\hline & $\begin{array}{l}\text { Technologies for remediation of dye wastes and } \\
\text { other processes }\end{array}$ & 7 \\
\hline & Vegetation and/or other biofuel source material & 2 \\
\hline \multirow{4}{*}{$\begin{array}{l}\text { Biomass } \\
\text { Bioenerg }\end{array}$} & Other biofuel production processes & 1 \\
\hline & Processing of lignocellulosic biomass & 1 \\
\hline & $\begin{array}{l}\text { Technologies for remediation of dye wastes and } \\
\text { other processes }\end{array}$ & 1 \\
\hline & Vegetation and/or other biofuel source material & 5 \\
\hline \multirow{3}{*}{$\begin{array}{l}\text { T ASABE/ } \\
\text { T ASAE }\end{array}$} & Biodiesel production processes & 1 \\
\hline & Soil properties & 1 \\
\hline & $\begin{array}{l}\text { Water quality, erosion or related environmental } \\
\text { modeling }\end{array}$ & 5 \\
\hline
\end{tabular}

J Irrig Drain Eng Evapotranspiration analysis

Note: ${ }^{\text {a }}$ The distribution of the top 50 cited articles shown here is based on search (Appendix A) results that were obtained on June 3, 2018 for 58,750 articles indexed in the WoS CC AE category for the 13 journals listed in Table 1.

${ }^{\mathrm{b}}$ The topics represent subjective groupings based on information in the article titles, abstracts and/or text. 
The citations for the subset of top cited comprehensive AE journal articles (Table 10) ranged from $2695^{[82]}$ to $175^{[96]}$. Articles published in TASABE/T ASAE dominated the distribution of top cited articles for the seven comprehensive AE journals and accounted for 14 of the top 15 cited articles, ranging from the top cited Moriasi et al. ${ }^{[82]}$ to 311 citations for Buffington et al. ${ }^{[97]}$ The lone exception among the top 15 cited articles was Thompson et al. ${ }^{[98]}$, which was published in Appl Eng Agric and accrued 333 citations at the time the search was performed. The remaining top cited articles were all published in Biosyst Eng/J Agr Eng Res (Table 10).

Table 10 Summary of the all-time top 50 cited comprehensive agricultural engineering journal articles that are indexed in the Web of Science Core Collection Agricultural Engineering category $^{\mathrm{a}}$

\begin{tabular}{|c|c|c|}
\hline Journal & General topic ${ }^{\mathrm{b}}$ & Total articles \\
\hline \multirow{10}{*}{$\begin{array}{l}\text { T ASABE } \\
/ T \text { ASAE }\end{array}$} & Biodiesel production processes & 5 \\
\hline & Food processing or properties & 2 \\
\hline & $\begin{array}{l}\text { Irrigation or other water resource management } \\
\text { issues }\end{array}$ & 1 \\
\hline & Livestock housing conditions & 1 \\
\hline & Measurement methods for agricultural materials & 6 \\
\hline & $\begin{array}{l}\text { Monitoring of soil erosion or in-stream } \\
\text { pollutants }\end{array}$ & 2 \\
\hline & Other biofuel production processes & 4 \\
\hline & Soil conservation practices & 2 \\
\hline & Soil properties & 2 \\
\hline & $\begin{array}{l}\text { Water quality, erosion or related environmental } \\
\text { modeling }\end{array}$ & 13 \\
\hline \multirow{7}{*}{$\begin{array}{l}\text { Biosyst Eng } \\
\text { /J Agr Eng Res }\end{array}$} & Food processing or properties & 3 \\
\hline & Livestock environmental issues & 2 \\
\hline & Livestock housing conditions & 2 \\
\hline & Measurement methods for agricultural materials & 1 \\
\hline & Remote sensing analysis & 1 \\
\hline & Soil properties & 2 \\
\hline & $\begin{array}{l}\text { Irrigation or other water resource management } \\
\text { issues }\end{array}$ & 1 \\
\hline \multicolumn{2}{|c|}{ Appl Eng Agric Biodiesel production processes } & 1 \\
\hline
\end{tabular}

Note: ${ }^{\text {a }}$ The distribution of the top 50 cited articles shown here is based on search (Appendix A) results that were obtained on June 3, 2018 for 58,750 articles indexed in the WoS CC AE category for the 13 journals listed in Table 1.

${ }^{\mathrm{b}}$ The topics represent subjective groupings based on information in the article titles, abstracts and/or text.

A considerably different distribution of topics emerges for the all-time top 50 cited articles that were determined for the seven comprehensive AE journals (Table 10), as compared to the distribution in Table 9. Dominant themes include water quality modeling and other environmentally related topics, water resource management and measurement methods. Biofuel related topics are an important subcategory but are clearly not dominant among the overall distribution of topics (Table 10). The striking differences between the Table 9 and 10 topical distributions provide further insight into the extensive differences in published content that characterize the comprehensive $\mathrm{AE}$ journals versus the specialty journals (Table 1). The Table 10 results also underscore that $T A S A B E / T A S A E$ has obtained a level of influence within the scientific community that exceeds initial impressions based on just the JIF (Table 5), at least for a smaller set of several dozen highly cited studies.

\section{Reflections on the Need for Revised JCR AE and WoS CC AE Journal Categories}

A “white paper" published by Thomson Reuters (2014) ${ }^{[99]}$ includes discussion regarding the importance of correctly evaluating and interpreting citation data, including the metrics reported in the JCR. The white paper further explicitly states: "The importance of interpreting and understanding these data correctly cannot be emphasized too strongly. Using quantitative citation data to measure impact is meaningful only in the context of journals in the same general discipline. For example, smaller fields like Agricultural Engineering do not generate as many articles or citations as larger fields like Biotechnology or Genetics." The authors of the white paper correctly identify the fact that the field of agricultural engineering is relatively small, as evidenced by the trends in total articles and citations reported above. And the authors also accurately note the need to compare metrics between journals within the context of specific disciplines, rather than trying to compare across disciplines that differ greatly in topical content, total articles published and rate of citations. However, the current mix of journals included in the JCR AE and WoS CC AE categories ironically contradicts the quote stated above, by literally comparing comprehensive AE journals versus biotechnology-related journals (see Tables 1 to 4 ).

\subsection{Structural and topical problems related to the specialty} journals

The problems related to including specialty journals in the JCR $\mathrm{AE}$ and WoS CC AE journal categories are most apparent regarding Bioresource Technol, Ind Crop Prod and Biomass Bioenerg, due to: (1) reporting of topical coverage that is very narrow relative to comprehensive AE journals (Table 3); (2) publication of considerably higher numbers of articles on average (e.g., Table 2); and (3) corresponding accrual of much higher rates of citations (Table 5 and Figure 1). In addition, Bioresource Technol and Biomass Bioenerg are both categorized in the JCR Biotechnology \& Applied Microbiology category (as well as the JCR Energy \& Fuels category), which is inconsistent with the position taken in Thomsen Reuters $(2014)^{[99]}$ white paper as noted above. Overall, these characteristics further confirm that the scientific communities that publish in these three specialty journals are very large and considerably different, relative to the counterpart communities that publish in the comprehensive AE journals (as also discussed in Section 2.1).

The publication, citation and metric characteristics for the $J$ Irrig Drain Eng, Paddy Water Environ and Aquacult Eng are more consistent with the corresponding characteristics of the comprehensive AE journals (Tables 2 and 5; Figure 1). However, these three journals are also structurally very different from the comprehensive AE journals (see again Tables 3 and 4). The $J$ Irrig Drain Eng focuses primarily on drainage and irrigation issues (Table 4) and is one of 38 journals published by the American Society of Civil Engineering (ASCE, 2018), which reflects the enormous size of the society relative to ASABE, EurAgEng and other agricultural engineering societies. The J Irrig Drain Eng is one of several water resource related journals published by ASCE (others include the J Hydraul Eng, J Hydrol Eng and J Water Resour Plan), all of which are potentially relevant to smaller subsets of the AE scientific community and are sometimes cited by authors publishing in comprehensive AE journals (or vice versa). Paddy Water Environ is defined on the journal website ${ }^{[57]}$ in the context of agricultural engineering but is specifically focused on 
rice paddy systems (Table 4), which is a minor research theme among the comprehensive AE journals. Similarly, Aquacult Eng publishes research that is focused solely on aspects of aquaculture production, a topic that is of very limited interest within the broader scientific communities that publish in comprehensive AE journals.

\subsection{Citation pattern issues between the comprehensive $\mathrm{AE}$} journals and specialty journals

A final aspect to consider is citation patterns between the comprehensive $\mathrm{AE}$ journals and the specialty journals currently indexed the JCR AE and WoS CC AE categories, as well as other relevant journals. Relevant citation relationships were investigated using the 2017 JCR "Cited Journal Data", which list citations from articles in other journals to articles in the journal of interest ${ }^{[101]}$, and "Citing Journal Data", which list citations from articles in the journal of interest to articles in other journals ${ }^{[102]}$. These two types of citation data are described in more detail in Appendix E. The specific citation data for the journals of interest are reported in Tables E. 2 and E. 3 and reflect aggregate citations between the reference journal and other specific journals of interest that have been accrued for over a decade. The focus of the citation pattern assessment is on the citation relationships between the Appl Eng Agric, Biosyst Eng, Int J Agr Biol Eng and T ASABE, based on overall international influence (Figure 1 and Table 7) among the seven comprehensive AE juornals, and other relevant journals. Note that the number of citations listed for a specific journal in Tables E. 2 and E. 3 should be viewed in the context of the overall total citations listed at the top of each data column for a given journal.

Selected Cited Journal Data and Citing Journal Data are reported for Bioresource Technol, Biomass Bioenerg and Ind Crop Prod (Table E.2), both in the context of inter-citation relationships between those three journals and versus Appl Eng Agric, Biosyst Eng, Int J Agr Biol Eng and T ASABE. These citation data reflect relatively strong inter-citation patterns between Bioresource Technol, Biomass Bioenerg and Ind Crop Prod, especially between Bioresource Technol and Biomass Bioenerg. In contrast, the two types of citation data reveal relatively weak citation relationships between the three specialty journals and the four comprehensive AE journals. This is due in part to the magnitude of citations that the two subsets of journals typically receive. But the primary reason is the fact that the overall spectrum of topic ranges between the two subsets of journals do not extensively overlap.

Table E.3 features selected Cited Journal Data and Citing Journal Data for Appl Eng Agric, Biosyst Eng, Int J Agr Biol Eng and $T A S A B E$, in the context of the other journals listed in Table 1 and eight other journals (Table E.1) that are characterized by relatively strong citation relationships with one or more of the four comprehensive $\mathrm{AE}$ journals. The four comprehensive $\mathrm{AE}$ journals tend to cluster near the top of each column in Table D.3, revealing overall strong citation patterns between those four journals. However, the Int J Agr Biol Eng has so far drawn only limited citations from articles published in Appl Eng Agric, Biosyst Eng and T ASABE (i.e., the Int J Agr Biol Eng cited data column in Table E.3) and in general has manifested weaker citation relationships with the other three journals to date. Notable citation patterns are shown across most of the Table E.3 data columns between the four comprehensive $\mathrm{AE}$ journals and Bioresource Technol, Biomass Bioenerg and J Irrig Drain Eng. However, a qualitative evaluation of the citation data in Table E.3 suggests that there are multiple journals listed in Table E.1 (i.e., Comput Electron Agr, Agr Water Manage, J Food Eng, J Environ
Qual) that are characterized by citation relationships with the four comprehensive AE journals that are as strong or stronger than the citation relationships demonstrated with Bioresource Technol, Biomass Bioenerg and J Irrig Drain Eng. Generally weak signals occur in terms of citations between the four comprehensive $\mathrm{AE}$ journals and Ind Crop Prod, Paddy Water Environ and Aquacult Eng, underscoring the overall lack of relationship between these three specialty journals and Appl Eng Agric, Biosyst Eng, Int J Agr Biol Eng and T ASABE.

Overall, the citation data presented in Tables E.2 and E.3 further confirm that there is no practical reason to include any of the six specialty journals (Tables 1 and 4 ) in the JCR AE and WoS CC AE journal categories. The citation data in Table E.3 also provide a glimpse of the broad sub-disciplines that intersect with comprehensive AE journals. For example, the strongest relationship across the four comprehensive AE journals was with Comput Electron Agr (Table E.3), which publishes computer-related research for a variety of agricultural and related subdisciplines including agronomy, horticulture, forestry, aquaculture, livestock production and food processing ${ }^{[103]}$. There is also a very discernible relationship between the four comprehensive $\mathrm{AE}$ journals and journals categorized as environmental science, ecology, soil science and/or water resource journals (Table E.1). This is consistent with the findings of Leydesdorff and Rafols (2009) ${ }^{[104]}$ who mapped the JCR AE category to a broader Environmental Sciences group that included Environmental Sciences and Water Resources among other JCR categories. A qualitative assessment of T ASABE Cited Journal Data and Citing Journal Data reveals particularly strong relationships with journals indexed in the JCR Environmental Sciences and Water Resource categories. In addition, four $T$ $A S A B E / T$ ASAE water quality or soil property related $\operatorname{articles}^{[74,77,82,83]}$ would be ranked in the top 100 all-time most cited articles in the WoS Water Resources category, of over 278000 articles currently indexed in that category, if the journal was also indexed in the JCR Water Resources category (search structure reported in Appendix A).

\subsection{Establishing more accurate JCR AE and WoS CC AE} journal categories

The specialty journals currently included in the JCR AE and WoS CC AE journal categories are all relevant to smaller subsets of scientists who identify as members of the agricultural engineering community and/or publish in comprehensive $\mathrm{AE}$ journals. However, that fact does not warrant inclusion of those specialty journals in the JCR AE and WoS CC AE categories. And as previously discussed, there are other specialty journals that are potentially just as or more relevant in the relational sphere that the comprehensive $\mathrm{AE}$ journals exist in. More importantly, the inherent differences between the comprehensive AE journals (Table 3 ) versus the specialty journals (Table 4) undermine the grouping of the two subsets of journals in the same JCR AE and WoS CC AE journal categories.

Comparison of JCR reported metrics between specific specialty journals versus comprehensive $\mathrm{AE}$ journals can be of logical interest to scientists who are seeking the most desirable outlet for publishing bioenergy related research or other research of potential interest to a specific journal. However, direct comparisons of such metrics to evaluate overall journal content within the context of the current JCR AE category should be avoided, due to the extensive differences between the two subsets of journals. Comprehensive AE journals should instead be compared directly 
only between each other. And the overall evaluation conducted here points to the need for revised JCR AE and WoS CC AE journal categories that include just comprehensive $\mathrm{AE}$ journals.

One potential problem with creating a specific comprehensive AE journals JCR category is the relatively small sample size of the subset of journals, which would consist of a total of only seven journals (Table 1) at present. This would likely result in statistical problems per the establishment of journal quartile rankings and other analyses for the specific category. However, this would eliminate the current distortion of the majority of comprehensive $\mathrm{AE}$ journals being ranked in the third $(\mathrm{Q} 3)$ or fourth $(\mathrm{Q} 4)$ quartiles, due to the inconsistent comparisons versus the specialty journals. In addition, this category could include comprehensive AE journals that are currently indexed in the Core Collection in the future. For example, the Journal of Agricultural Engineering ${ }^{[105]}$ and INMATEH - Agricultural Engineering ${ }^{[106]}$ are currently indexed in the WoS CC ESCI database and may ultimately be indexed in the WoS CC SCIE database and JCR database. And as noted previously, there are a number of other comprehensive AE journals that may warrant consideration for inclusion in the WoS CC in the future, such as Canadian Biosystems Engineering ${ }^{[34]}$, Agricultural Engineering International: CIGR Journal ${ }^{[35]}$ and Research in Agricultural Engineering ${ }^{[107]}$.

\section{Conclusions and recommendations}

The review of the JCR AE and WoS CC AE journal categories reveals dichotomies per the journals currently indexed as $\mathrm{AE}$ journals. Bioresource Technol, Biomass Bioenerg and Ind Crop Prod are unquestionably the dominant journals in terms of the JIF and other journal metrics. However, those three journals are also characterized by radically different topical content, publication rates and citation accruals relative to the comprehensive $\mathrm{AE}$ journals, indicating that direct comparisons between the two subsets of journals are not realistic. Incongruent overall topical content also undermines any rational basis for direct comparisons between J Irrig Drain Eng, Paddy Water Environ and Aquacult Eng and the comprehensive AE journals, in spite of similar publication and citation rates.

Biosyst Eng has emerged as the premier journal among the comprehensive AE journals, when those journals are evaluated on the basis of the JIF and 5-year JIF. However, T ASABE consistently draws more total citations and is further characterized by more very highly cited studies, which underscores that journals should be evaluated by a variety of metrics; the latter point is an aspect of journal evaluation that is strongly stressed by Clarivate Analytics $^{[108]}$. Biosyst Eng also draws citations from a much broader cross section of individual countries than the other comprehensive $\mathrm{AE}$ journals, indicating that the journal has established a stronger overall global presence at present relative to the similar journals evaluated here.

Publication trends evaluated in this study show that the total number of articles that are published annually in the JCR AE and WoS CC AE journal categories increased by roughly a factor of 3 during the time period of 2006 to 2016 . However, the primary reason for this increase was due to large increases in the number of articles published in Bioresource Technol, Biomass Bioenerg and Ind Crop Prod over that time period. The publication trends also revealed that Chinese scientists are publishing articles at an increasingly higher rate in the $13 \mathrm{AE}$ journals and that Chinese institutions have become the dominant contributors to JCR AE and WoS CC AE journal categories. However, it is important to recognize that members of $\mathrm{AE}$ department faculties and scientists in related fields regularly publish in journals indexed in Water Resource, Environmental Science and other JCR categories, and that scientists in unrelated fields publish at times in the AE-indexed journals.

Some specific recommendations are also offered regarding the current to JCR AE and WoS CC AE journal categories:

1) Scientists and others who are interested in performing in-depth evaluations of different comprehensive AE journals, based on journal metrics and other factors, should limit those assessments to the subset of comprehensive AE journals (Table 1) that are indexed in the JCR AE and WoS CC AE journal categories.

2) Direct comparisons between comprehensive $\mathrm{AE}$ journals and specialty journals can be a rational approach when individual researchers and research teams are interested in determining desirable publication outlets for biofuel, water quality, aquaculture or any other specific type of studies. However, it should be kept in mind that comprehensive AE journals will typically have lower JIF values and other journal metrics, relative to competing specialty journals, due to the lower accrual of citations that occurs for comprehensive $\mathrm{AE}$ journals (which is further exacerbated by smaller subsdisciplines that routinely publish in comprehensive AE journals).

3) The review conducted here points to the need for revised JCR AE and WoS CC AE journal categories that consist solely of comprehensive $\mathrm{AE}$ journals. It is possible that a secondary category could be developed that includes relatively strongly related specialty journals, but those mix of journals would be considerably different as compared to the current distribution of journals in the JCR AE and WoS CC AE categories.

\section{[References]}

[1] Mays L W. A brief history of water technology during antiquity: Before the Romans. In: Mays L W (Ed.). Ancient Water Technologies. Heidelberg, Germany: Springer Dordrecht, 2010; pp.1-28.

[2] Tamburrino A. Water technology in ancient Mseopotamia. In: Mays L W (Ed.). Ancient Water Technologies. Heidelberg, Germany: Springer Dordrecht, 2010; pp.29-51.

[3] Mays L W, Gorokhovich Y. Water technology in the ancient American societies. In: Mays L W (Ed.). Ancient Water Technologies. Heidelberg, Germany: Springer Dordrecht, 2010; pp.171-200.

[4] Bizzarri C, Soren D. Etruscan domestic architecture, hydraulic engineering, and water management technologies innovations and legacy to Rome. In: Bell S, Carpino A A (Ed.). A Companion to the Etruscans New York, NY. John Wiley \& Sons, Inc. 2015; pp.129-145. https://onlinelibrary.wiley.com/doi/book/10.1002/9781118354933. Accessed on [2018-02-22]

[5] Mays L W. A brief history of Roman water technology. In: Mays L W (Ed.). Ancient Water Technologies. Heidelberg, Germany: Springer Dordrecht, 2010; pp.115-137.

[6] Leigh D S, Kowalewski S A, Holdridge G. 3400 years of agricultural engineering in Mesoamerica: lama-bordos of the Mixteca Alta, Oaxaca, Mexico. Journal of Archaeological Science, 2013; 40: 4107-4111. doi: 10.1016/j.jas.2013.05.009.

[7] ASABE. Part 2. Timeline in the development of agricultural field Implements, related apparatus, and equipment. St. Joseph, MI: American Society of Agricultural and Biological Engineers. 2018. https://www.asabe.org/media/129817/timelinespart2.pdf. Accessed on [2018-02-22].

[8] Smith G S. McCormick, Cyrus Hall: (15 February 1809-13 May 1884) Oxford, United Kingdom: Oxford University Press, 2018. http://www.anb.org/view/10.1093/anb/9780198606697.001.0001/anb-978 0198606697-e-1001098. Accessed on [2018-02-22].

[9] Ricci T. Jethro Tull: Biography. New York, NY: American Society of Mechanical Engineers. https://www.asme.org/engineering-topics/ articles/history-of-mechanical-engineering/jethro-tull. Accessed on [2018-02-22]. 
[10] Mirsky J, Nevins A. The World of Eli Whitney. Science and Society, 1953; 17(3): 282-284.

[11] Herrmann K. Milestones in the history of agricultural engineering. Landtechnik, 2011; 66(4): 297-299. doi: 10.15150/lt.2011.415.

[12] AEA. The Agricultural Engineers Association: The voice of the agricultural, environmental and amenity machinery sectors. Hampton, Peterborough, United Kingdom. 2012. http://www.aea.uk.com/. Accessed on [2018-03-24].

[13] ASABE. ASABE - 100 years of innovation: Engineering for a sustainable future. St. Joseph, MI: American Society of Agricultural and Biological Engineers. 2018. https://www.asabe.org/about-us/history.aspx. Accessed on [2018-02-22].

[14] DBBE. The first century forward: Bioproducts and Biosystems Engineering at the University of Minnesota 1909-2009. Department of Bioproducts and Biosystems Engineering, Institute of Technology, University of Minnesota. https://bbe.umn.edu/sites/bbe.umn.edu/files/ BBEs\%20Rich\%20History.pdf. Accessed on [2018-03-20].

[15] TAMU. Department of Biological and Agricultural Engineering. Texas A\&M University, College Station, Texas. 2018. https://baen.tamu.edu/ about/history/. Accessed on [2018-03-19].

[16] Bateman H P, Foster W A, Jones, Jr. B A, Lembke W D. Agricultural Engineering on the Prairie: Illinois Style: A history of the University of Illinois Department of Agricultural Engineering, 1921-1997. Urbana-Champaign, IL: Department of Agricultural Engineering, University of Illinois. 1998. https://abe.illinois.edu/about/history. Accessed on [2018-02-22].

[17] PSU. The History of the Department. Department of Agricultural and Biological Engineering, Pennsylvania State University, University Park, Pennsylvania. 2018. https://abe.psu.edu/about/brief-history-ofdepartment. Accessed on [2018-10-09].

[18] Wrest Park History Contributors. Chapter 1: The early years: 1924-1947. Biosystems Engineering, 2009; 103(Supplement 1): 6-18. doi: 10.1016/j.biosystemseng.2008.11.018.

[19] Wrest Park History Contributors. Chapter 2: The Wrest Park years 1948-2006. Biosystems Engineering, 2009; 103 (Supplement 1): 19-35. doi: 10.1016/j.biosystemseng.2008.11.029.

[20] Hansen E L, McColly H F, Stone A A, Davidson J B. Introducing Agricultural Engineering in China. Agricultural and Biosystems Engineering Technical Reports and White Papers. 14. Ames, IA: Department of Agricultural and Biosystems Engineering. http://lib.dr.iastate.edu/abe_eng_reports/14?utm_source=lib.dr.iastate.edu $\% 2 F a b e \_$eng_reports\%2F14\&utm_medium=PDF\&utm_campaign=PDFC overPages. Accessed on [2018-03-02].

[21] Dinglai T. Brief history of agricultural engineering development in China: In memory of Mr. Zou Bingwen. International Journal of Agricultural and Biological Engineering, 2008; 1(1): 8-11. doi: 10.3965/j.issn.1934-6344.2008.01.008-011

[22] Zhou X, Dong R, Li S, Peng G, Zhang L, Hou J, et al. Agricultural Engineering in China. Agricultural Engineering International: CIGR Journal, 2003; $5 . \quad$ http://www.cigrjournal.org/index.php/Ejounral/issue/ view/24. Accessed on [2018-03-21].

[23] EurAgEng. European Society for Agricultural Engineers: The European network for engineering and systems in the rural sector. Cranfield, United Kingdom. 2016. https://www.eurageng.eu/. Accessed on [2018-03-24].

[24] CSAE. Chinese Society of Agricultural Engineering. Beijing, China. 2018. http://www.csae.org.cn/ (in Chinese). Accessed on [2018-11-09].

[25] SEAg. Society for Engineering in Agriculture. Faculty of Engineering and Surveying, University of Southern Queensland, Toowoomba, Australia. 2018. https://www.engineersaustralia.org.au/CommunitiesAnd-Groups/Technical-Societies/Society-For-Engineering-In-Agriculture. Accessed on [2018-03-19].

[26] CIGR. Member Organizations. International Commission of Agricultural Engineering. University of Florida, Gainesville, Florida, 2018. http://cigr.org/Who-We-Are/member-organizations.php\#. Accessed on [2018-03-18].

[27] CIGR. About CIGR: Who We Are. International Commission of Agricultural Engineering. University of Florida, Gainesville, Florida. 2018. http://cigr.org/Who-We-Are/about.php\#. Accessed on [2018-03-18].

[28] ASAE. Agricultural Engineering. The Journal of the American Society of Agricultural Engineers. American Society of Agricultural Engineers, St. Joseph, Michigan. 1920. ALMA21193510520002756\&context=
L\&vid=01IASU\&lang=en_US\&search_scope=ComboPrimocentral\&adapt or=Local\%20Search\%20Engine \&tab=default_tab\&query=title,exact,Agric ultural\%20Engineering,AND\&sortby=rank\&mode=advanced\&pfilter=pfil ter,exact,journals,AND\&offset=0. Accessed on [2018-11-09].

[29] ASABE. Transactions of the ASAE: Vol. 1 No. 1 1958. St. Joseph, MI: American Society of Agricultural and Biological Engineers. 2018. https://elibrary.asabe.org/toc_journals.asp?volume=1\&issue $=1 \&$ conf $=t \& c$ onfalias $=t 1 \& \operatorname{orgconf}=t 1958$. Accessed on [2018-09-04]

[30] ASABE. Applied Engineering in Agriculture: Vol. 1 No. 1 1985. St. Joseph, MI: American Society of Agricultural and Biological Engineers. 2018. https://elibrary.asabe.org/toc_journals.asp?volume=1\&issue= $1 \&$ conf $=$ aeaj\&confalias=aeaj\&orgconf=aeaj1985. Accessed on [2018-09-04].

[31] Elsevier. Biosystems Engineering. Amsterdam. The Netherlands: Elsevier B.V. 2018. https://www.journals.elsevier.com/biosystemsengineering. Accessed on [2018-03-19].

[32] Elsevier. Journal of Agricultural Engineering Research. Amsterdam. The Netherlands: Elsevier B.V. 2018. https://www.sciencedirect.com/ journal/journal-of-agricultural-engineering-research. Accessed on [2018-03-19].

[33] CSAE. International Journal of Agricultural and Biological Engineering. Chinese Society of Agricultural Engineering, Beijing, China. 2018. https://www.ijabe.org. Accessed on [2018-03-18].

[34] CSBE. Canadian Biosystems Engineering. Canadian Society for Bioengineering, University of Manitoba, Winnipeg, Manitoba. 2018. https://csbe-scgab.ca/publications/cbe-journal. Accessed on [2018-03-18].

[35] CIGR. Agricultural Engineering International: CIGR Journal. Chinese Academy of Agricultural Mechanization Sciences (CAAMS), Beijing, China. 2018. Accessed on [2018-03-18].

[36] PAGEPress. Journal of Agricultural Engineering. Italian Society of Agricultural Engineering. Pavia, Italy: PAGEPress srl Scientific Publications. https://www.agroengineering.org/index.php/jae/about/ journalSponsorship. Accessed on [2018-03-06].

[37] SBEA. Engenharia Agrìcola. Brazilian Association of Agricultural Engineering, São Paulo State University, Castellane, São Paulo, Brazil. 2018a.

http://www.scielo.br/scielo.php?script=sci_serial\&pid=0100-6916\&lng=en $\& n r m=i s o$. Accessed on [2018-03-26].

[38] Bollen J, Van de Sompel H, Hagberg A, Chute R. A Principal Component Analysis of 39 Scientific Impact Measures. PLoS ONE, 2009; 4(6): e6022. doi: 10.1371/journal.pone.0006022.

[39] Clarivate Analytics. Know your metrics: Immediacy Index. Philadelphis, PA: Clarivate Analytics. 2018. https://clarivate.com/blog/science-research-connect/research-management/ know-your-metrics-immediacy-index/. Accessed on [2018-03-26].

[40] Clarivate Analytics. Journal Citation Reports: Quick reference guide. Philadelphis, PA: Clarivate Analytics. 2018 https://clarivate.libguides.com/jcr. Accessed on [2018-03-23].

[41] Harzing A-W. Publish or Perish: Metrics. Anne-Wil Harzing, Middelsex University, London, United Kingdom. 2018 https://harzing.com/resources/publish-or-perish\#metrics.

[42] Harzing A-W. Publish or Perish 4 User's Manual: Citation Metrics. Anne-Wil Harzing, Middelsex University, London, United Kingdom. 2016. https://harzing.com/pophelp/metrics.htm.

[43] Elsevier. Research Metrics. Amsterdam, The Netherlands: Elsevier B.V. 2018. https://www.elsevier.com/solutions/scopus/features/ metrics. Accessed on [2018-03-19].

[44] Univ. of Michigan. Research impact metrics: citation analysis Research Guides, University of Michigan Library, Ann Arbor, Michigan. 2018. http://guides.lib.umich.edu/c.php?g=282982\&p=3408326. Accessed on [2018-03-23].

[45] Garfield E. Citation indexes for science: A new dimension in documentation through association of ideas. Science, 1955; 122(3159): 108-111. doi: 10.1126/science.122.3159.108.

[46] Garfield E, Sher I H. New factors in the evaluation of scientific literature through citation indexing. Journal of the Association for Information Science and Technology, 1963; 14(3): 195-201. doi: 10.1002/asi.5090140304.

[47] Bensman S J. 2007. Garfield and the impact factor. Ann. Rev. of Infor. Sci. Tech., 41(1): 93-155. doi: 10.1002/aris.2007.1440410110.

[48] Lawlor, B. 2014. The Institute for Scientific Information: A brief history. In: McEwen, L et al. (Ed.): The Future of the History of 
Chemical Information, ACS Symposium Series, Vol. 1164. Washington, D.C.: American Chemical Society. pp. 109-126.

[49] Thomsen Reuters. 2016. Thomson Reuters Announces Definitive Agreement to Sell its Intellectual Property \& Science Business to Onex and Baring Asia for \$3.55 billion. New York, NY. http://thomsonreuters.com/en/press-releases/2016/july/thomson-reuters-an nounces-definitive-agreement-to-sell-its-intellectual-property-science-busi ness.html. Accessed on [2016-04-09].

[50] Cision. Acquisition of the Thomson Reuters Intellectual Property and Science Business by Onex and Baring Asia completed. New York, NY: Cision PR Newswire. https://www.prnewswire.com/news-releases/ acquisition-of-the-thomson-reuters-intellectual-property-and-science-busin ess-by-onex-and-baring-asia-completed-300337402.html. Accessed on [2018-06-14].

[51] Clarivate Analytics. Web of Science Databases. Philadelphis, PA: Clarivate Analytics. 2018. https://clarivate.com/products/web-ofscience/databases/. Accessed on [2018-03-23].

[52] Clarivate Analytics. Incites help: Journal Impact Factor. Philadelphis, PA: Clarivate Analytics. 2018. http://ipscience-help.thomsonreuters. com/inCites2Live/indicatorsGroup/aboutHandbook/ usingCitationIndicatorsWisely/jif.html. Accessed on [2018-03-31]

[53] Clarivate Analytics. Master journal list: Scope notes. Philadelphis, PA: Clarivate Analytics. 2018. http://mjl.clarivate.com/scope/. Accessed on [2018-03-31].

[54] Clarivate Analytics. Incites Journal Citation Reports Help: What's New in Journal Citation Reports?: 2018 JCR release. Philadelphis, PA: Clarivate Analytics. 2018. http://ipscience-help.thomsonreuters.com /incitesLiveJCR/whatsNewGroup/whatsNewJCR.html. Accessed on [2018-03-23].

[55] Clarivate Analytics. 2017 Journal Citation Reports: Journals in the 2017 release of JCR. Philadelphis, PA: Clarivate Analytics. 2017. https://mafiadoc.com/2017-journal-citation-reports_5b85a2b8097c479e2e8 b45e7.html. Accessed on [2018-11-09].

[56] Elsevier. Industrial Crops and Products. Amsterdam, The Netherlands: Elsevier B.V. 2018. https://www.journals.elsevier.com/industrialcrops-and-products. Accessed on [2018-03-24].

[57] SpringerLink. Paddy and Water Environment. Heidelberg, Germany: Springer Verlag. 2018. https://link.springer.com/journal/10333. Accessed on [2018-03-24].

[58] Hall C W, Olsen W C. The literature of agricultural engineering. Ithaca, New York: Cornell University Press, 1992; 416p.

[59] Basselman J A, Chancellor W. Publishing of the American Society of Agricultural Engineers. In: Hall C W, Olsen W C. (Ed.): The literature of agricultural engineering. Ithaca, New York: Cornell University Press, 1992; pp.175-196.

[60] Olsen W C. Primary journals and reports. In: Hall C W, Olsen W C. (Ed.): The literature of agricultural engineering. Ithaca, New York: Cornell University Press, 1992; pp.318-331.

[61] Wang Y, Tian C. Introduction of agricultural engineering journals embodied by databases of EI and SCI, etc. Transactions of the CSAE, 2012; 28(2): 316-322. (in Chinese)

[62] Zhang K, Wang L. Citation analysis on articles of Transactions of the CSAE cited by SCI journals. Transactions of the CSAE, 2017; 33(1): 381-387. (in Chinese).

[63] Larivière V, Haustein S, Mongeon P. The oligopoly of academic publishers in the digital era. PLOS One, 2015; 10(6): e0127502. doi: 10.1371/journal.pone.012750.

[64] DEAg-CTRN-UFCG. Revista Brasileira de Engenharia Agricola Ambiental: Instructions to the authors. Departamento de Engenharia Agrícola, Centro de Tecnologia e Recursos Naturais, Universidade Federal de Campina Grande. 2018. http://www.scielo.br/revistas/rbeaa/ iinstruc.htm. Accessed on [2018-03-26].

[65] SBEA. Engenharia Agrìcola: Instructions to authors. Brazilian Association of Agricultural Engineering, São Paulo State University, Castellane, São Paulo, Brazil. 2018. http://www.scielo.br/revistas/ eagri/iinstruc.htm. Accessed on [2018-03-26].

[66] Elsevier. Biosystems Engineering: Open access options. Amsterdam. The Netherlands: Elsevier B.V. 2018. https://www.elsevier.com/ journals/biosystems-engineering/1537-5110/open-access-options. Accessed on [2018-03-26].

[67] Elsevier. Aquacultural Engineering: Open access options. Amsterdam. The Netherlands: Elsevier B.V. 2018. https://www.elsevier.com/ journals/aquacultural-engineering/0144-8609/open-access-options.
Accessed on [2018-03-26].

[68] Springer. Open Choice: Your research; Your choice. Heidelberg, Germany: Springer Verlag. 2018. http://www.springer.com/us/ open-access/springer-open-choice. Accessed on [2018-03-26].

[69] Creative Commons. About the licenses. Mountain View, California: Creative Commons. 2018. https://creativecommons.org/licenses/. Accessed on [2018-03-26].

[70] Clarivate Analytics. Incites Journal Citation Reports help: Total cites. Philadelphis, PA: Clarivate Analytics. 2018e. http://ipscience-help.thomsonreuters.com/incitesLiveJCR/glossaryAZgrou p/g13/7411-TRS.html. Accessed on [2018-03-31].

[71] Clarivate Analytics. The clarivate analytics impact factor. Philadelphis, PA: Clarivate Analytics. 1994. https://clarivate.com/essays/ impact-factor/. Accessed on [2018-03-31].

[72] Clarivate Analytics. Incites help: 5-year journal impact factor. Philadelphis, PA: Clarivate Analytics. 2018. http://ipscience-help.thomsonreuters.com/inCites2Live/indicatorsGroup/ aboutHandbook/usingCitationIndicatorsWisely/fiveYearJIF.html. Accessed on [2018-03-31].

[73] Liu W, Liu F, Zuo C, Zhu J. The effect of publishing a highly cited paper on a journal's impact factor: A case study of the Review of Particle Physics. Learned Publishing, 2018. doi: 10.1002/leap.1156.

[74] Rawls W J, Brakensiek D L, Saxton S E. Estimation of Soil Water Properties. Transactions of the ASABE, 1982; 25(5): 1316-1320. doi: 10.13031/2013.33720.

[75] Williams J R, Jones C A, Dyke P T. A modeling approach to determining the relationship between erosion and soil productivity. Transactions of the ASABE, 1984; 27(1): 129-144

[76] Williams J R, Jones C A, Kiniry J R, Spanel D A. The EPIC crop growth model. Transactions of the ASABE, 1989; 32(2): 0497-0511. doi: $10.13031 / 2013.31032$.

[77] Leonard R A, Knisel W G, Still D A. GLEAMS: Groundwater loading effects of agricultural management systems. Transactions of the ASABE, 1987; 30(5): 1403-1418. doi: 10.13031/2013.30578.

[78] Canakci M, Van Gerpen J. Biodiesel production from oils and fats with high free fatty acids. Transactions of the ASAE, 2001; 44(6): 1429-1436. doi: 10.13031/2013.7010.

[79] Canakci M, Van Gerpen J. Biodiesel production via acid catalysis Transactions of the ASAE, 1999; 2(5): 1203-1210. doi: 10.13031/2013.13285.

[80] Nearing M A, G. R. Foster, L. J. Lane, S. C. Finkner. A process-based soil erosion model for USDA-Water Erosion Prediction Project Technology. Transactions of the ASABE, 1989; 32(5): 1587-1593. doi $10.13031 / 2013.31195$.

[81] Harmel R D, Cooper R J, Slade R M, Haney R L, Arnold J G. Cumulative uncertainty in measured streamflow and water quality data for small watersheds. Transactions of the ASABE, 2006; 49(3): 689-701. doi: 10.13031/2013.20488)

[82] Moriasi D N, Arnold J G, Van Liew M W, Bingner R L, Harmel R D, Veith T L. Model evaluation guidelines for systematic quantification of accuracy in watershed simulations. Transactions of the ASABE, 2007; 50(3): 885-900. doi: 10.13031/2013.23153.

[83] Gassman P W, Reyes M, Green C, Arnold J G. The soil and water assessment tool: Historical development, applications, and future research directions. Trans ASABE, 2007; 50(4): 1211-50. doi: 10.13031/2013.23634

[84] Arnold J G, Moriasi D N, Gassman P W, Abbaspour K C, White M J, Srinivasan R, et al. SWAT: Model use, calibration, and validation. Transactions of the ASABE, 2012; 55(4): 1491-1508. doi: $10.13031 / 2013.42256$.

[85] Liu W, Tang L, Gu M, Hu G. Feature report on China: A bibliometric analysis of China-related articles. Scientometrics, 2015; 102(1): 503-517. doi: 10.1007/s11192-014-1371-y.

[86] Liu W, Hub G, Tang L, Wang Y. China's global growth in social science research: Uncovering evidence from bibliometric analyses of SSCI publications (1978-2013). Journal of Informetrics, 2015; 9(3): 555-569. doi: 10.1016/j.joi.2015.05.007. (in Chinese)

[87] Cobo M J, Martínez M A, Gutiérrez-Salcedo M, Fujita H, Herrera-Viedma E. 25 years at Knowledge-Based Systems: A bibliometric analysis. Knowledge-Based Systems, 2015; 80: 3-13. doi: 10.1016/j.knosys. 2014.12.035.

[88] Mao G, Zou H, Chen G, Du H, Zuo J. Past, current and future of biomass energy research: A bibliometric analysis. Renewable and Sustainable 
Energy Reviews, 2015; 52: 1823-1833. doi: 10.1016/j.rser.2015.07.141.

[89] Chen H-Q, Wang X, He L, Chen P, Wan Y, Yang L, et al. Chinese energy and fuels research priorities and trend: A bibliometric analysis. Renewable and Sustainable Energy Reviews, 2016; 58: 966-975. doi: 10.1016/j.rser.2015.12.239

[90] Wang M, Liu D, Jia J, Zhang X. Global trends in soil monitoring research from 1999-2013: a bibliometric analysis. Acta Agriculturae Scandinavica, Section B: Soil \& Plant Science, 2015; 65(6): 483-495. doi: T10.1080/09064710.2015.1030443.

[91] Wang Y, Xiang C, Zhao P, Mao G, Du H. A bibliometric analysis for the research on river water quality assessment and simulation during 2000-2014. Scientometrics, 2016; 108(3): 1333-1346. doi: 10.1007/s11192-016-2014-2.

[92] Wang L. The structure and comparative advantages of China's scientific research: quantitative and qualitative perspectives. Scientometrics, 2016; 106: 435-452. doi: 10.1007/s11192-015-1650-2. (in Chinese)

[93] Mosier N, Wyman C, Dale B, Elander R, Lee, Y Y, Holtzapple M, et al. Features of promising technologies for pretreatment of lignocellulosic biomass. Bioresource Technology, 2004; 96(6): 673-686. doi: 10.1016/j.biortech.2004.06.025.

[94] Allen R G, Tasumi M, Trezza R. Satellite-based energy balance for mapping evapotranspiration with internalized calibration (METRIC) model. Journal of Irrigation and Drainage Engineering, 2007; 133(4): 380-394. doi: 10.1061/(ASCE)0733-9437(2007)133:4(380).

[95] Alvira P, Tomas-Pejo E, Ballesteros M, Negro M J. Pretreatment technologies for an efficient bioethanol production process based on enzymatic hydrolysis: A review. Bioresource Technology, 2010; 101(13): 4851-4861. doi: 10.1016/j.biortech.2009.11.093.

[96] Stone, M L, Solie, J B, Raun, W R, Whitney, R W, Taylor, S L, Ringer, J D. Use of spectral radiance for correcting in-season fertilizer nitrogen deficiencies in winter wheat. Transactions of the ASAE, 1996; 39(5): 1623-1631. doi: 10.13031/2013.27678.

[97] Thompson J C, He B B. Characterization of crude glycerol from biodiesel production from multiple feedstocks. Applied Engineering in Agriculture, 2006; 22(2): 261-265. doi: 10.13031/2013.20272.

[98] Buffington D E, Collazo-Arocho A, Canton G H, Pitt D, Thatcher W W, Collier R J. Black Globe-Humidity Index (BGHI) as comfort equation for dairy cows. Transactions of the ASABE, 1981; 24(3): 0711-0714. doi: $10.13031 / 2013.34325$

[99] Thomsen Reuters. Connecting the dots across the research ecosystem: A white paper. 2014. Available at: wokinfo.com/media/pdf/connecting the_dots.pdf. Accessed on [2018-02-18].

[100] ASCE. ASCE library: journals. Reston, VA: American Society of Civil Engineers. https://ascelibrary.org/journals. Accessed on [2018-15-06]

[101] Clarivate Analytics. Incites journal citation reports help: Cited journal data. Philadelphis, PA: Clarivate Analytics. 2018 http://ipscience-help.thomsonreuters.com/incitesLiveJCR/JCRGroup/ jcrJournalProfile/jcrJournalProfileCitedJournal.html. Accessed on [2018-08-06]

[102] Clarivate Analytics. Incites journal citation reports help: Citing journal data. Philadelphis, PA: Clarivate Analytics. 2018 http://ipscience-help.thomsonreuters.com/incitesLiveJCR/JCRGroup/ jcrJournalProfile/jcrJournalProfileCitingTab.html. Accessed on [2018-08-06].

[103] Elsevier. Computers and Electronics in Agriculture. Amsterdam, The Netherlands: Elsevier B.V. 2018. https://www.journals.elsevier.com/ computers-and-electronics-in-agriculture. Accessed on [2018-06-13].

[104] Leydesdorff L, Rafols I. A global map of science based on the ISI subject categories. Journal of the American Society for Information Science and Technology, 2009; 60(2): 348-362. doi: 10.1002/asi.20967.

[105] INMA. INMATEH - Agricultural Engineering. Bucharest, Romania: National Institute of Research-Development for Machines and Installations Designed to Agriculture and Food Industry - INMA. http://www.inmateh.eu/index_eng.htm. Accessed on [2018-13-06].

[106] CAAS. Research in Agricultural Engineering (RAE). Czech Academy of Agricultural Sciences, Prague, Czech Republic. https://www.agriculturejournals.cz/web/rae/. Accessed on [2018-09-09].

[107] Clarivate Analytics. Evaluate the world's leading scientific and scholarly journals: Using the Journal Impact Factor wisely. Philadelphis, PA: Clarivate Analytics. 2017. https://clarivate.com/products/ journal-citation-reports/. Accessed on [2018-16-06].

[108] SpringerLink. Applied Biological Chemistry. Heidelberg, Germany: Springer Verlag. 2018. https://link.springer.com/journal/13765. Accessed on [2018-03-24].

Appendix A: JCR or WoS search structures for information of data reported in the Introduction, Tables 9 and 10, and Section 4.2 Introduction: The identification of the beginning of the JCR AE category was determined by searching on selected years in the current Incites Journal Citation Reports database, within the overall Web of Science database. Selecting the year 1999 reveals that the Agricultural Engineering category does not exist. However, selecting the year 2000 shows the Agricultural Engineering category for the first time (with nine journals listed). Some of the originally indexed agricultural engineering journals (e.g., TASAE and J Agr Eng Res) are indexed prior to the year 2000 in the JCR Engineering category.

Table 9: This advanced search structure includes all of the relevant journals that were indexed in the 2017 JCR AE category (see Table 1), plus the Journal of Agricultural Engineering Research and T ASAE (which are the original names for Biosyst Eng and T ASABE).

$\mathrm{SO}=($ AMA-AGR MECH ASIA AF or APPL ENG AGRIC or AQUACULT ENG or BIOMASS BIOENERG or BIORESOURCE TECHNOL or BIOSYST ENG or ENGENHARIA AGRICOLA or IND CROP PROD or INT J AGR BIOL ENG or J IRRIG DRAIN ENG or J AGR ENG RES or PADDY WATER ENVIRON or REVISTA BRASILEIRA DE ENGENHARIA AGRICOLA E AMBIENTAL or T ASAE or T ASABE)

Note: The Table 9 search structure does not include APPL BIOL CHEM, which is the new name that was adopted in 2016 for the original $\mathrm{J}$ KOREAN SOC APPL BI (as listed in Tables A.1, A.2, A.4 and A.5). The old name was indexed in the 2016 and 2017 JCR data, as explained in the main text and Appendix A. The name was indexed in the 2016 WoS CC.

Table 10: This search structure includes the relevant comprehensive agricultural journals (see Table 1) that were indexed in the 2017 JCR AE category, plus the Journal of Agricultural Engineering Research and T ASAE (which are the original names for Biosyst Eng and T ASABE)

SO = (AMA-AGR MECH ASIA AF or APPL ENG AGRIC or BIOSYST ENG or ENGENHARIA AGRICOLA or INT J AGR BIOL ENG or J AGR ENG RES or REVISTA BRASILEIRA DE ENGENHARIA AGRICOLA E AMBIENTAL or T ASAE or T ASABE)

Water Resources category search: As noted in Section 4.2, an advanced WoS CC search was performed for the Water Resources category to determine the 100 highest cited articles cited in that category (to compare against top cited T ASABE/T ASAE water quality and soil property related articles). There are currently 88 journals indexed in the JCR Water Resources category, which were too many to perform a "SO search" such as were performed for Tables 9 and 10 as described above. So a general search using the "WC" command (described further in Appendix C) was performed as follows:

$$
\mathrm{WC}=\text { Water Resources }
$$

The search resulted in returning a listing of 280979 articles that were indexed in the Water Resources category as of June 5, 2018. 
Appendix B: Versions of Tables 1, 2, 4 and 5, and Figures 1 and 2, that include information for The Journal of the Korean Society for Applied Biological Chemistry

The revelation that The Journal of the Korean Society for Applied Biological Chemistry (J Korean Soc Appl Bi) was included by mistake in the 2016 and 2017 JCR AE journal categories (Hubbard, S. Personal communication. 2018. Content Team Lead, JCR, Clarivate Analytics, Philadephia, PA) posed a dilemma for this study. Excluding the Korean Soc Appl Bi from the study would result in an inconsistent set of journals per those that were actually reported in the JCR over those two years. However, including the journal in the study would result in essentially meaningless journal metric comparisons and other analyses, because the $J$ Korean Soc Appl Bi was actually never intended to be compared with the other journals indexed in the JCR AE and WoS CC AE categories.

To address this conundrum, the decision was made to exclude the $J$ Korean Soc Appl Bi from the primary study but to also provide several parallel tables and figures in this appendix that include data for the journal. No additional supporting text is provided in this appendix for these parallel tables and figures, but comparisons can be made between them and those in the text to gain insights as to how the $J$ Korean Soc Appl Bi would have ranked versus the other journals for several measures. The table and figure numbering is consistent with the comparable tables reported in the text.

Table B.1 Classifications, JIF rank, journal titles, professional society, publisher and publication characteristics for the 14 journals indexed in the 2017 JCR Agricultural Engineering Category (including the $J$ Korean Soc Appl Bi) ${ }^{\text {a }}$

\begin{tabular}{|c|c|c|c|c|c|c|c|c|}
\hline Classification & $\begin{array}{c}\text { JIF } \\
\text { Rank }^{b}\end{array}$ & Full journal title & $\begin{array}{l}\text { Abbreviated journal } \\
\text { title }^{\mathrm{c}}\end{array}$ & $\begin{array}{l}\text { Society }^{\mathrm{d}} \\
\text { (country) }\end{array}$ & Publisher (country) & $\begin{array}{l}\text { Publication } \\
\text { frequency }\end{array}$ & Initial year & $\begin{array}{l}\text { Publication } \\
\text { model }^{\mathrm{e}}\end{array}$ \\
\hline \multirow{7}{*}{$\begin{array}{c}\text { Specialty topic } \\
\text { agricultural } \\
\text { engineering journals } \\
\text { (abbreviation: } \\
\text { specialty) }\end{array}$} & 1 & $\begin{array}{l}\text { Bioresource } \\
\text { Technology }\end{array}$ & $\begin{array}{c}\text { Bioresource } \\
\text { Technol }\end{array}$ & $N A^{f}$ & $\begin{array}{c}\text { Elsevier B.V. } \\
\text { (The Netherlands) }\end{array}$ & $<$ monthly & 1991 & $\begin{array}{c}\text { Traditional } \\
\text { (supports OA) }\end{array}$ \\
\hline & 2 & Biomass \& Bioenergy & Biomass Bioenerg & NA & $\begin{array}{c}\text { Elsevier B.V. } \\
\text { (The Netherlands) }\end{array}$ & Monthly & 1991 & $\begin{array}{c}\text { Traditional } \\
\text { (supports OA) }\end{array}$ \\
\hline & 3 & $\begin{array}{l}\text { Industrial Crops and } \\
\text { Products }\end{array}$ & Ind Crop Prod & NA & $\begin{array}{c}\text { Elsevier B.V. } \\
\text { (The Netherlands) }\end{array}$ & $\begin{array}{l}\text { Monthly to } \\
<\text { monthly }\end{array}$ & 1992 & $\begin{array}{c}\text { Traditional } \\
\text { (supports OA) }\end{array}$ \\
\hline & 5 & $\begin{array}{l}\text { Journal of Irrigation and } \\
\text { Drainage Engineering }\end{array}$ & J Irrig Drain Eng & $\begin{array}{c}\text { ASCE } \\
\text { (United States) }\end{array}$ & $\begin{array}{c}\text { ASCE } \\
\text { (United States) }\end{array}$ & Monthly & 1956 & Traditional \\
\hline & 6 & Aquacultural Engineering & Aquacult Eng & $\begin{array}{c}\text { AES } \\
\text { (United States) }\end{array}$ & $\begin{array}{c}\text { Elsevier B.V. } \\
\text { (The Netherlands) }\end{array}$ & $\begin{array}{l}\text { Quarterly to } \\
\text { bimonthly }\end{array}$ & 1982 & $\begin{array}{c}\text { Traditional } \\
\text { (supports OA) }\end{array}$ \\
\hline & 8 & $\begin{array}{l}\text { Paddy and Water } \\
\text { Environment }\end{array}$ & $\begin{array}{l}\text { Paddy Water } \\
\text { Environ }\end{array}$ & $\begin{array}{l}\text { PAWEES } \\
\text { (Japan) }\end{array}$ & $\begin{array}{l}\text { Springer Verlag } \\
\text { (Germany) }\end{array}$ & Quarterly & 2003 & $\begin{array}{c}\text { Traditional } \\
\text { (supports OA) }\end{array}$ \\
\hline & 10 & $\begin{array}{l}\text { Journal of the Korean } \\
\text { Society for Applied } \\
\text { Biological Chemistry }\end{array}$ & $\begin{array}{c}\text { J Korean Soc Appl } \\
\text { Bi }\end{array}$ & $\begin{array}{c}\text { KSABC } \\
\text { (South Korea) }\end{array}$ & $\begin{array}{l}\text { Springer Verlag } \\
\text { (Germany) }\end{array}$ & Bimonthly & 1948 & Traditional \\
\hline \multirow{7}{*}{$\begin{array}{c}\text { Comprehensive } \\
\text { agricultural } \\
\text { engineering journals } \\
\text { (abbreviation: } \\
\text { comprehensive) }\end{array}$} & 4 & Biosystems Engineering & Biosyst Eng & $\begin{array}{c}\text { EurAgEng } \\
\text { (United Kingdom) }\end{array}$ & $\begin{array}{c}\text { Elsevier B.V. } \\
\text { (The Netherlands) }\end{array}$ & Monthly & $2002^{\mathrm{g}}$ & $\begin{array}{c}\text { Traditional } \\
\text { (supports OA) }\end{array}$ \\
\hline & 7 & $\begin{array}{c}\text { Transactions of the } \\
\text { ASABE }\end{array}$ & T ASABE & $\begin{array}{c}\text { ASABE } \\
\text { (United States) }\end{array}$ & $\begin{array}{c}\text { ASABE } \\
\text { (United States) }\end{array}$ & Bimonthly & 1958 & Traditional \\
\hline & 9 & $\begin{array}{l}\text { International Journal of } \\
\text { Agricultural and } \\
\text { Biological Engineering }\end{array}$ & Int J Agr Biol Eng & $\begin{array}{c}\text { CSAE \& } \\
\text { AOCABFE } \\
\text { (Peoples R China) }\end{array}$ & $\begin{array}{c}\text { CASE } \\
\text { (Peoples R China) }\end{array}$ & Bimonthly & 2008 & Open access \\
\hline & 11 & $\begin{array}{c}\text { Revista Brasileira de } \\
\text { Engenharia Agricola e } \\
\text { Ambiental }\end{array}$ & $\begin{array}{c}\text { Rev Bras Eng Agr } \\
\text { Amb }\end{array}$ & NA & $\begin{array}{c}\text { DEAg-CTRN-UFCG } \\
\text { (Brazil) }\end{array}$ & Monthly & 1997 & Open access \\
\hline & 12 & $\begin{array}{l}\text { Applied Engineering in } \\
\text { Agriculture }\end{array}$ & Appl Eng Agric & $\begin{array}{c}\text { ASABE } \\
\text { (United States) }\end{array}$ & $\begin{array}{c}\text { ASABE } \\
\text { (United States) }\end{array}$ & Bimonthly & 1985 & Traditional \\
\hline & 13 & Engenharia Agricola & Eng Arg-Jaboticabal & $\begin{array}{l}\text { SBEA } \\
\text { (Brazil) }\end{array}$ & SBEA (Brazil) & Bimonthly & 1972 & Open access \\
\hline & 14 & $\begin{array}{c}\text { AMA-Agricultural } \\
\text { Mechanization in Asia } \\
\text { Africa and Latin America }\end{array}$ & $\begin{array}{l}\text { Ama-Arg Mech Asia } \\
\text { Af }\end{array}$ & NA & $\begin{array}{l}\text { Shin-Norinsha Co., Ltd. } \\
\text { (Japan) }\end{array}$ & Quarterly & 1971 & Traditional \\
\hline
\end{tabular}

Note: ${ }^{\text {a }}$ The $2017 \mathrm{JCR}^{[54,55]}$ reports citation data recorded in 2016.

${ }^{\mathrm{b}} \mathrm{JIF}$ rank is reported in the $2017 \mathrm{JCR}$ as listed in Table 5 in section 2.2.

${ }^{\mathrm{c}}$ Abbreviated journal title names as reported in the JCR Agricultural Engineering category.

${ }^{\mathrm{d}}$ Definitions of society abbreviations: AES = Aquacultural Engineering Society (https://www.aesweb.org/); ASCE = American

Society of Civil Engineering (https://www.asce.org/); PAWEES = International Society of Paddy and Water Environment

Engineering (http://pawees.net/); KSABC = The Korean Society for Applied Biological Chemistry (http://www.ksabc.or.kr/ english/); EurAgEng = European Society for Agricultural Engineers (https://www.eurageng.eu/); CSAE = Chinese Society of Agricultural Engineering (http://www.csae.org.cn/); AOCABFE = Association of Overseas Chinese Agricultural, Biological, and Food Engineers (http://aocabfe.com/); ASABE = American Society of Agricultural and Biological Engineers (http://www.asabe.org/); SBEA = Brazilian Association of Agricultural Engineering (http://www.sea.org.br/)

${ }^{\mathrm{e}}$ Traditional = no articles are published open access; Traditional (supports OA) = open access articles are possible for a fee; open access = all of the articles are published open access (also requires publication fees)

${ }^{\mathrm{f}} \mathrm{NA}=$ not applicable

${ }^{\mathrm{g}}$ The journal name was changed in 2016 to Applied Biological Chemistry ${ }^{[108] \mathrm{h}}$ Biosyst Eng was previously published as the J Agr Eng Res between 1956 and $2001^{[32]}$

i DEAg-CTRN-UFCG = Departamento de Engenharia Agrícola, Centro de Tecnologia e Recursos Naturais, Universidade Federal de Campina Grande (http://www.scielo.br/revistas/rbeaa/iaboutj.htm). 
Table B.2 Total number of articles published in each of the 14 journals (including the $J$ Korean Soc Appl Bi) indexed in the JCR Agricultural Engineering category for 2015 and 2016

\begin{tabular}{|c|c|c|c|c|}
\hline \multirow{2}{*}{ JCR journal title } & Total articles & Proportion/\% & Total articles & Proportion $/ \%$ \\
\hline & \multicolumn{2}{|c|}{2015} & \multicolumn{2}{|c|}{2016} \\
\hline Bioresource Technol & 1537 & 37.69 & 1615 & 40.12 \\
\hline Ind Crop Prod & 937 & 22.98 & 713 & 17.71 \\
\hline Biomass Bioenerg & 356 & 8.73 & 317 & 7.88 \\
\hline Biosyst Eng & 164 & 4.02 & 193 & 4.80 \\
\hline Aquacult Eng & 52 & 1.28 & 45 & 1.12 \\
\hline $\mathrm{J}$ Irrig Drain Eng & 158 & 3.87 & 176 & 4.37 \\
\hline Int J Agr Biol Eng & 106 & 2.60 & 133 & 3.30 \\
\hline T ASABE & 154 & 3.78 & 203 & 5.04 \\
\hline Paddy Water Environ & 51 & 1.25 & 47 & 1.17 \\
\hline J Korean Soc Appl Bi & 122 & 2.99 & 111 & 2.76 \\
\hline Rev Bras Eng Agr Amb & 180 & 4.41 & 180 & 4.47 \\
\hline Eng Agr-Jaboticabal & 113 & 2.77 & 125 & 3.11 \\
\hline Ama-Agr Mech Asia Af & 53 & 1.30 & 63 & 1.57 \\
\hline Total & 4078 & 100 & 4025 & 100 \\
\hline
\end{tabular}

Note: ${ }^{a}$ Reported in the WoS CC AE data ${ }^{[51]}$.

Table B.4 Primary research areas covered by specialty topic journals ${ }^{\mathrm{a}}$ in the JCR Agricultural Engineering category including the J Korean Soc Appl Bi

\begin{tabular}{|c|c|c|}
\hline Journal $^{\text {b }}$ & Additional JCR categories & Primary research topics \\
\hline Bioresource Technol & $\begin{array}{l}\text { Biotechnology \& Applied Microbiology; } \\
\text { Energy \& Fuels }\end{array}$ & $\begin{array}{l}\text { Biofuels, bioprocesses and bioproducts; biomass and feedstocks utilization, thermochemical } \\
\text { conversion of biomass, biological waste treatment }\end{array}$ \\
\hline Biomass Bioenergy & $\begin{array}{l}\text { Biotechnology \& Applied Microbiology; } \\
\text { Energy \& Fuels }\end{array}$ & $\begin{array}{l}\text { Biomass, biological residues, bioenergy processes, bioenergy utilization, biomass and the } \\
\text { environment }\end{array}$ \\
\hline J Irrig Drain Eng & Engineering; Civil; Water Resources & $\begin{array}{l}\text { All phases of irrigation, drainage, engineering hydrology, and related water management } \\
\text { subjects including water quality, groundwater and surface water }\end{array}$ \\
\hline Paddy Water Environ & Agronomy & $\begin{array}{l}\text { Irrigation and drainage, soil and water conservation, land and water resources management, } \\
\text { paddy multi-functionality, and other aspects of paddy farming }\end{array}$ \\
\hline J Korean Soc Appl Bi & Food Science and Technology & $\begin{array}{l}\text { Biochemistry, molecular biology, biotechnology, natural and synthetic bioactive compounds, } \\
\text { and bio-environmental interactions }\end{array}$ \\
\hline
\end{tabular}

Note: ${ }^{a}$ See Table 1 for additional details about each journal.

${ }^{\mathrm{b}}$ Sources: Bioresource Technol (https://www.journals.elsevier.com/bioresource-technology/); Ind Crop Prod (https://www.journals.elsevier.com/industrial-crops-andproducts); Biomass Bioenergy (https://www.journals. elsevier.com/biomass-and-bioenergy); Aquacult Eng (https://www.journals.elsevier.com/aquacultural-engineering); J Irrig Drain Eng (https://ascelibrary.org/page/jidedh/editorialboard); Paddy Water Environ (https://link.springer.com/journal/10333); J Korean Soc Appl Bi (https://link.springer.com/journal/13765).

Table B.5 Total cites, JIF and 5-year JIF values reported for the 14 JCR Agricultural Engineering category journals (including the $J$ Korean Soc Appl Bi) for citation data recorded in $2016^{\mathrm{a}}$

\begin{tabular}{|c|c|c|c|c|}
\hline Journal title & Total cites & JIF & 5-Year JIF & Classification \\
\hline Bioresource Technol & 93612 & 5.651 & 6.102 & specialty \\
\hline Biomass Bioenerg & 18312 & 3.219 & 4.186 & specialty \\
\hline Ind Crop Prod & 15116 & 3.181 & 3.577 & specialty \\
\hline Biosyst Eng & 4495 & 2.044 & 2.238 & comprehensive \\
\hline J Irrig Drain Eng & 3434 & 1.983 & 1.842 & specialty \\
\hline Aquacult Eng & 1917 & 1.559 & 2.004 & specialty \\
\hline Paddy Water Environ & 609 & 0.916 & 1.218 & specialty \\
\hline Int J Agr Biol Eng & 503 & 0.835 & - & comprehensive \\
\hline J Korean Soc Appl Bi & 630 & 0.750 & 0.671 & specialty \\
\hline Rev Bras Eng Agr Amb & 1311 & 0.608 & 0.78 & comprehensive \\
\hline Appl Eng Agric & 1590 & 0.505 & 0.667 & comprehensive \\
\hline Eng Agr-Jaboticabal & 686 & 0.353 & 0.59 & comprehensive \\
\hline Ama-Agr Mech Asia Af & 106 & 0.118 & 0.087 & comprehensive \\
\hline
\end{tabular}

Note: ${ }^{a} 2016$ statistics are reported in the 2017 JCR published by Clarivate Analytics ${ }^{[54,55]}$. 


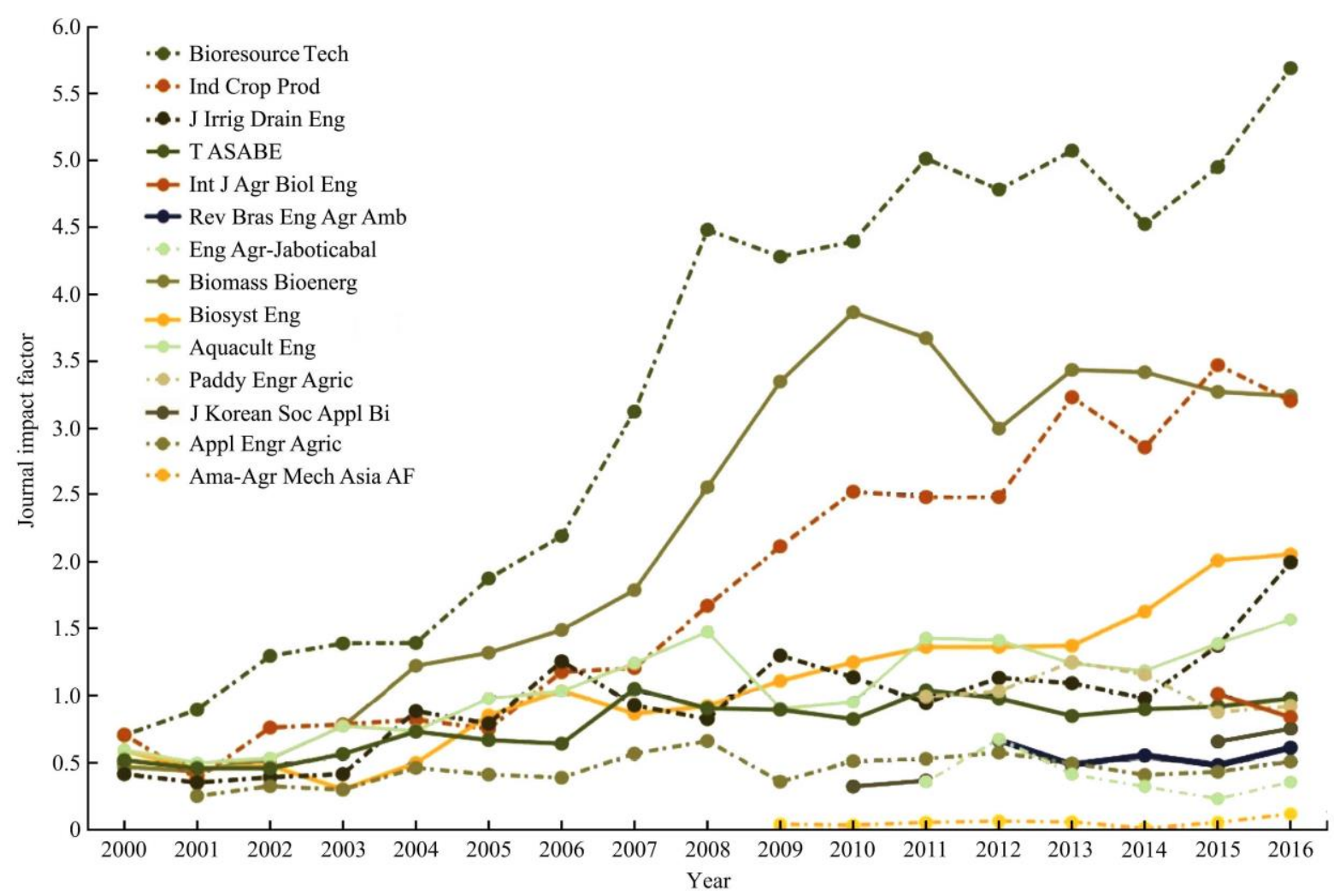

Figure B.1 Long-term trends in JIF values for the 14 journals indexed in the JCR Agricultural Engineering category including the $J$ Korean Soc Appl Bi ${ }^{[54]}$

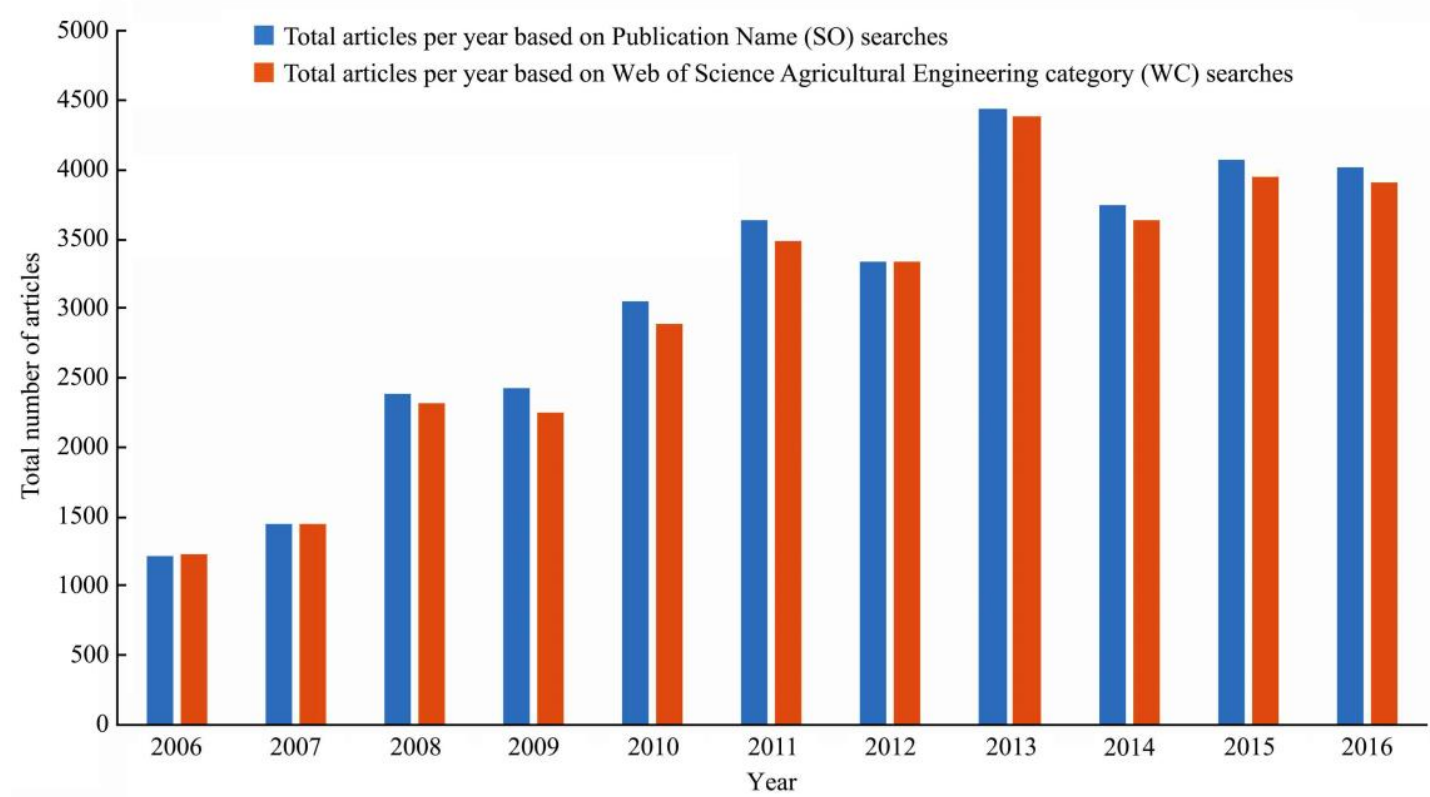

Figure B.2 Total articles indexed in the WoS Core Collection Agricultural Engineering category, including the $J$ Korean Soc Appl Bi, using two different types of search structures as described in Appendix C

Appendix C. JIF values based on 2017 citation data, and extended long-term JIF trends, for the journals reported in the 2018 JCR AE category

The data included in Appendix C includes the JIF values reported for the 2018 JCR AE category journals, based on 2017 citation data and long-term JIF trends for the journals that include the JIF values reported in the 2018 JCR. The error that resulted in the $J$ Korean Soc Appl Bi being included in the 2016 and 2017 JCR AE categories occurred again for the 2018 JCR (A. Prasad. Personal communication. 2018. Customer Care - Technical Support, Clarivate Analytics, Philadephia, PA). Thus Table C.1 reports the 2018 JCR JIF values without the $J$ Korean Soc Appl Bi data and is analogous to Table 5 in the text. Table C.2 includes the J Korean Soc Appl Bi data and is analogous to Table B.5 in Appendix B. Similarly, Figures C.1 and C.2 reflect the exclusion and inclusion of the J Korean Soc Appl Bi data, respectively, and are identical to the respective Figure 1 in the text or Figure B.1 in Appendix B except that 2017 citation data is included for each of the AE journals. 
Table C.1 Total cites, JIF and 5-year JIF values reported for the 13 JCR Agricultural Engineering category journals (excluding the $J$ Korean Soc Appl Bi) for citation data recorded in $2017^{\text {a }}$

\begin{tabular}{|c|c|c|c|c|}
\hline Journal title & Total cites & JIF & 5-Year JIF & Classification \\
\hline Bioresource Technol & 101191 & 5.807 & 5.978 & specialty \\
\hline Ind Crop Prod & 19421 & 3.849 & 4.072 & specialty \\
\hline Biomass Bioenerg & 19706 & 3.358 & 4.232 & specialty \\
\hline Biosyst Eng & 5044 & 2.132 & 2.325 & comprehensive \\
\hline J Irrig Drain Eng & 3468 & 1.616 & 1.714 & specialty \\
\hline Paddy Water Environ & 703 & 1.379 & 1.293 & specialty \\
\hline Int J Agr Biol Eng & 765 & 1.267 & - & comprehensive \\
\hline T ASABE & 9260 & 1.118 & 1.475 & comprehensive \\
\hline Rev Bras Eng Agr Amb & 1523 & 0.619 & 0.801 & comprehensive \\
\hline Appl Eng Agric & 1796 & 0.497 & 0.698 & comprehensive \\
\hline Eng Agr-Jaboticabal & 707 & 0.387 & 0.611 & comprehensive \\
\hline
\end{tabular}

Note: ${ }^{a} 2017$ statistics are reported in the 2018 JCR published by Clarivate Analytics ${ }^{[54]}$.

Table C.2 Total cites, JIF and 5-year JIF values reported for the 13 JCR Agricultural Engineering category journals (including the $\mathrm{J}$ Korean Soc Appl Bi) for citation data recorded in $2017^{\mathrm{a}}$

\begin{tabular}{|c|c|c|c|c|}
\hline Journal title & Total cites & JIF & 5-Year JIF & Classification \\
\hline Bioresource Technol & 101191 & 5.807 & 5.978 & specialty \\
\hline Ind Crop Prod & 19421 & 3.849 & 4.072 & specialty \\
\hline Biomass Bioenerg & 19706 & 3.358 & 4.232 & specialty \\
\hline Biosyst Eng & 5044 & 2.132 & 2.325 & comprehensive \\
\hline J Irrig Drain Eng & 3468 & 1.616 & 1.714 & specialty \\
\hline Aquacult Eng & 1957 & 1.490 & 2.111 & specialty \\
\hline Paddy Water Environ & 703 & 1.379 & 1.293 & specialty \\
\hline Int J Agr Biol Eng & 765 & 1.267 & - & comprehensive \\
\hline J Korean Soc Appl Bi & 686 & 1.129 & 0.840 & specialty \\
\hline T ASABE & 9260 & 1.118 & 1.475 & comprehensive \\
\hline Rev Bras Eng Agr Amb & 1523 & 0.619 & 0.801 & comprehensive \\
\hline Appl Eng Agric & 1796 & 0.497 & 0.698 & comprehensive \\
\hline Eng Agr-Jaboticabal & 707 & 0.387 & 0.611 & comprehensive \\
\hline AMA-Agr Mech Asia Af & 107 & 0.150 & 0.147 & comprehensive \\
\hline
\end{tabular}

Note: ${ }^{\text {a }} 2017$ statistics are reported in the 2018 JCR published by Clarivate Analytics ${ }^{[54]}$.

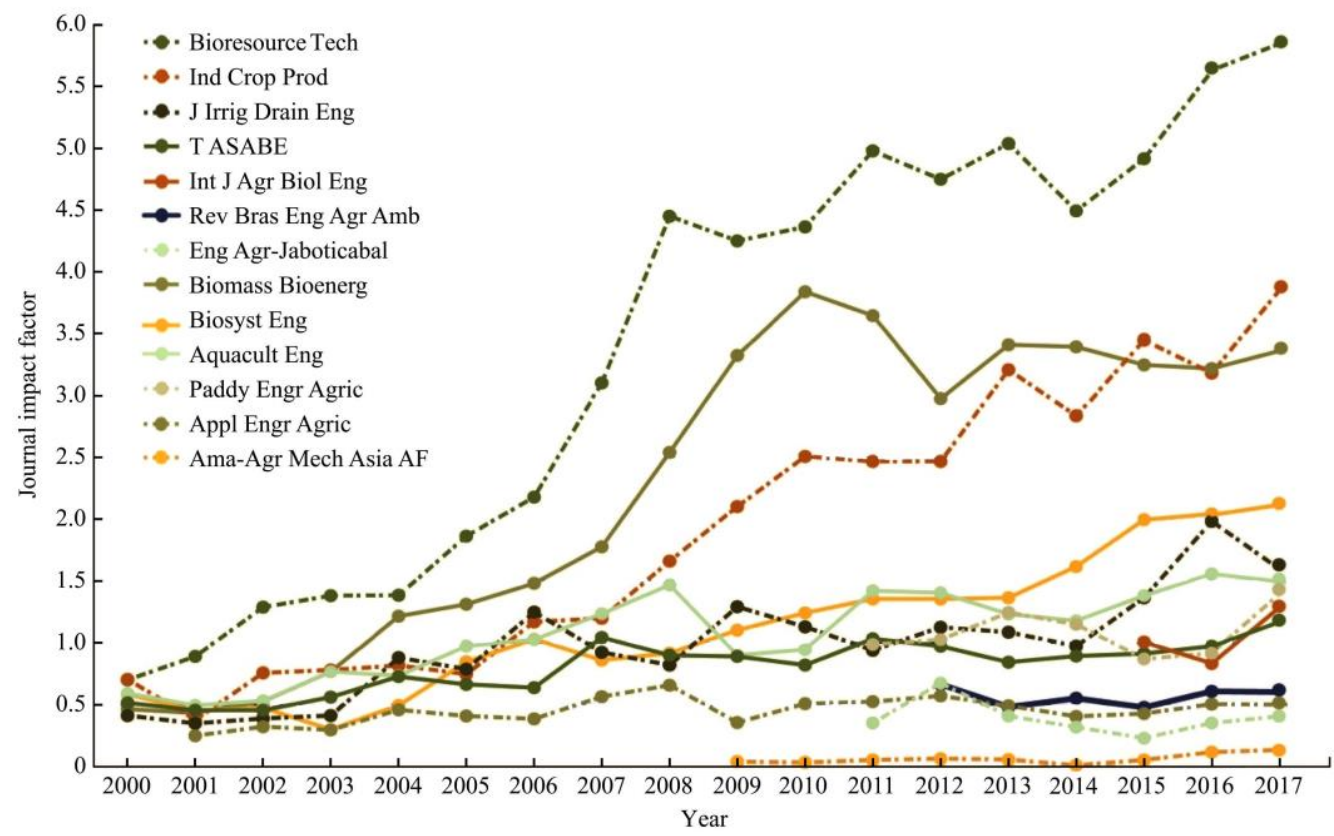

Figure C.1 Long-term trends in JIF values for the 14 journals indexed in the JCR Agricultural Engineering category excluding the $J$ Korean Soc Appl Bi ${ }^{[54]}$ 


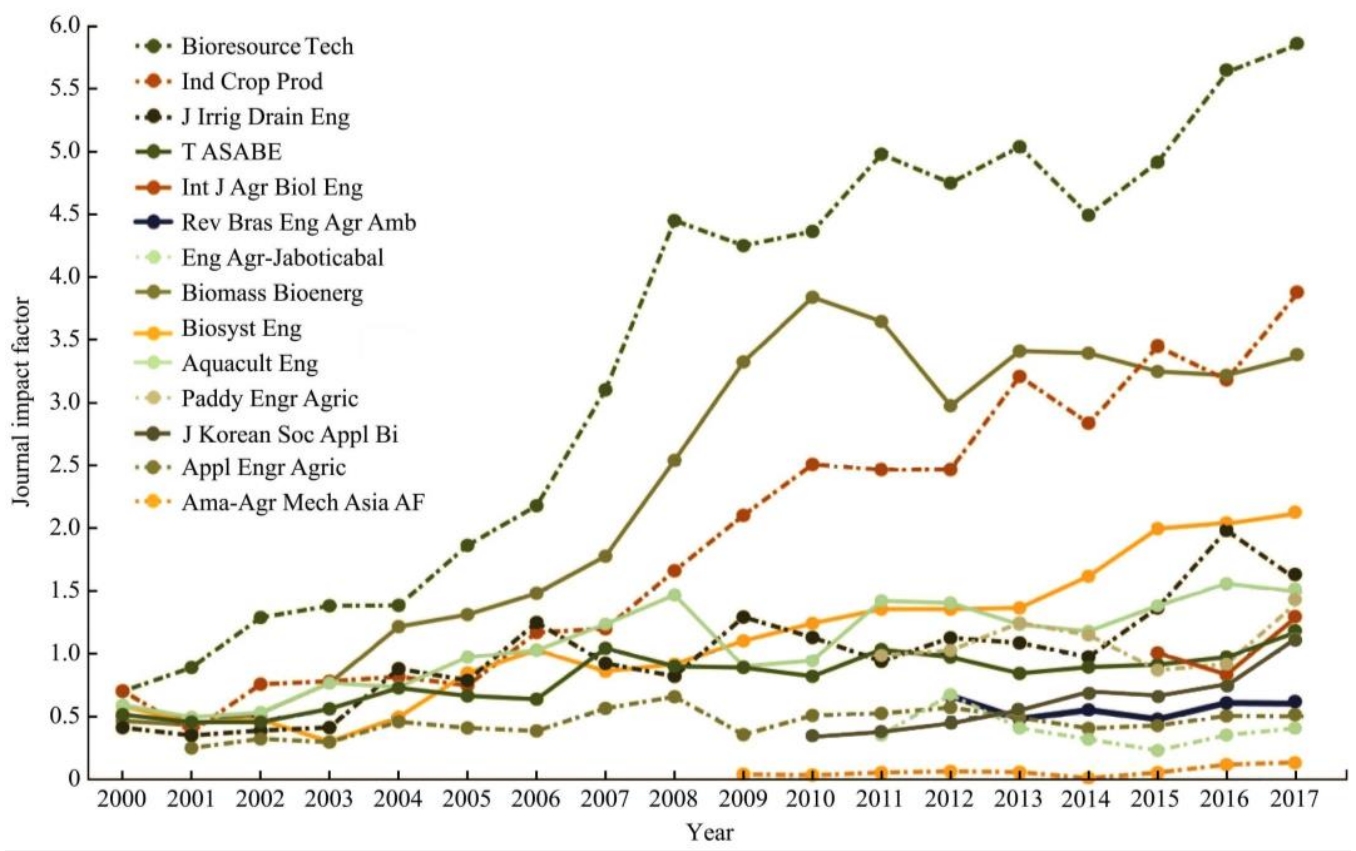

Figure C.2 Long-term trends in JIF values for the 14 journals indexed in the JCR Agricultural Engineering category including the $J$ Korean Soc Appl Bi ${ }^{[54]}$

Appendix D. Description of Searches for Agricultural Engineering Journals, and Resulting Total Published Articles by Year, that are Indexed in the WoS Core Collection

Section 3 describes data generated using ad vanced searches within the WoS Core Collection Agricultural Engineering category, such as the total articles published in the category by year (Figure 2). The WoS platform provides two methods for performing advanced searches that return the total number of articles and other data related to the journals indexed in a specific WoS category, which are as follows:

1) $\mathrm{WC}=\mathrm{Web}$ of Science Category

2) $\mathrm{SO}=$ Publication name, which is constructed as: $\mathrm{SO}=$ (journal name 1 or journal name 2 or ..., etc.)

As noted in Section 3, "apparent anomalies" were encountered regarding how some of the journals are indexed in the JCR Agricultural Engineering category versus the WoS Core Collection Agricultural Engineering category (and also internally within the WoS Core Collection). However, explanations for these discrepancies were provided by Clarivate Analytics, which are described in more detail below along with corresponding adjustments that were incorporated in the search structures. Results of both search methods are reported in Figure 2, which vary in total articles reported for each year.

Regarding the two search methods described above, the first was very straight forward and simply consisted of using "WC = Agricultural Engineering" for each year between 2006 and 2016, to determine the total number of articles published in the category each year. The search was also limited to just the SCIE database, out of the ten different WoS databases that were available. Otherwise, potentially hundreds of additional articles are reported, which are published in numerous other journals, conference proceedings and other publications that are indexed in various non-SCIE WoS databases (e.g., ESCI, CPCI-S). The results of the WC searches are reported in the respective WC columns by year in Table D.1.

The SO search structures required identifying the appropriate sets of journals each year, based on which sets of journals were reported in the JCR between 2006 and 2016. The specific SO search structures are listed below by year, including explanations as to why certain journals were excluded or included, based partially on the guidance provided by Clarivate Analytics.

Several of the journals were indexed in both the JCR and WoS Core Collection Agricultural Engineering categories across the entire time period and thus appear in every search. Those journals included Appl Eng Agric, Aquacult Eng, Biomass Bioenerg, Bioresource Technol, Biosyst Eng, Ind Crop Prod, J Irrig Drain Eng and T ASABE (although J Irrig Drain Eng-ASCE had to also be used for J Irrig Drain Eng for several years as discussed below). Several other journals were indexed one or more years later than 2006, initially in the WoS Core Collection and then two years later in the JCR AE category; i.e., Agrartech Forsch-Agr, AMA-Agr Mech Asia Af, Eng Agr-Jaboticabal, Rev Bras Eng Agr Amb and Int J Agr Biol Eng, which were indexed respectively in the Core Collection in 2007, 2007, 2008, 2010 and 2013, and then subsequently in the JCR in 2009, 2009, 2010, 2012 and 2015 (Agrartech Forsch-Agr was only indexed for one year in both databases, due to the journal ceasing publication in 2008).

The apparent anomalies pertained to the following journals listed listed in Table D.1: J Irrig Drain Eng, J Irrig Drain Eng-ASCE and Paddy Water Environ. Problems were also encountered that pertained to J Korean Soc Appl Bi (and revised title Appl Biol Chem in 2016). Explanations for these issues are provided below based on the responses provided by Clarivate Analytics (Hubbard, S. Personal communication. Content Team Lead, JCR, Clarivate Analytics, Philadephia, PA). The adjustments for the search structures are listed below each explanation. A standard rule that was adopted within the search structures, as part of some of the solutions, is the assumption that a journal was indexed in the WoS CC AE category two years before it first appears in the JCR AE category. This is consistent with the relationship that exists for other indexed agricultural engineering journals as described above.

The apparent anomalies encountered, the explanations based on the guidance provided by Clarivate Analytics (which are summarized here) 
and the adjustments adopted for the SO search structures are as follows:

1) Irrigation Sci is listed in the JCR AE category but not in the WoS AE category for the years 2006 to 2010.

Explanation: Irrigation Sci was originally indexed in the JCR AE category for the years 2006 to 2010 . But the 2006 to 2010 WoS categories now reflect just the current indexing of Irrigation Sci in the Agronomy and Water Resources categories.

Adjustment: This change was overcome by incorporating Irrigation Sci in the SO search structures for 2006 to 2010.

2) The titles J Irrig Drain Eng and J Irrig Drain Eng-ASCE are used for the same journal in the WoS Agricultural Engineering category during the years 2006 to 2013. However, the journal is listed only as the J Irrig Drain Eng-ASCE in the JCR Agricultural Engineering category during 2006 to 2012 and as J Irrig Drain Eng during 2013 to 2016 (implying a journal name change between 2012 and 2013).

Explanation: The journal title and abbreviation were in fact changed in the JCR and WoS in 2013 by dropping the -ASCE suffix (the same change was made for several other American Society of Civil Engineering journals at that time per the society's request). A general recommendation is to be inclusive as possible in the search structure to account for possible differences in the journal source title.

Adjustment: Both titles were used in the initial SO searchers between 2006 and 2013 to ensure that all of the articles that were published in the journal during those years were accounted for. Interestingly, it was discovered that the J Irrig Drain Eng-ASCE title disappeared several weeks later (by June 25, 2018) and that searching on just J Irrig Drain Eng returned all of the articles published in each year (as shown in Table D.1).

3) Paddy Water Environ is indexed in the WoS CC AE category during 2006 to 2008 but is not indexed in the JCR AE category during those same three years.

Explanation: Paddy Water Environ was accepted to the WoS CC (SCIE Database) in 2009 and later indexed in the JCR in 2011. However, previous issues were backfilled into the WoS CC for 2003 to 2008.

Adjustment: Paddy Water Environ was included in the SO searches starting in 2009.

4) $\mathrm{J}$ Korean Soc Appl Bi is indexed in the JCR Agricultural Engineering category in 2011, 2012, 2015 and 2016 but is not indexed in the WoS CC AE category during those four years.

Explanation: The journal was indexed correctly in the 2011 and 2012 JCR AE categories but was incorrectly indexed in the 2016 and 2017 JCR AE categories.

Adjustment: The journal was excluded from all SO searches, to remain consistent with the decision to not include the $J$ Korean Soc Appl Bi in the overall analyses (see Introduction, Table 1 and Appendix A).

5) The title of J Korean Soc Appl Bi was changed to Appl Biol Chem in 2016 as described at https://www.springer.com/chemistry/ biotechnology/journal/13765?detailsPage=press (also noted in footnote G, Table B1 in Appendix B). The correct revised title is indexed in the WoS CC AE category in 2016 but still appears as J Korean Soc Appl Bi the 2017 JCR AE category.

Explanation: Both titles appear in the 2017 JCR data, the former with a Journal Impact Factor, and the latter with an Immediacy Index only. This is due to the normal sequence of events that occurs when a journal changes title in the JCR.

Adjustment: As noted for anomaly 4 immediately above, the journal was excluded from all SO searches, to remain consistent with the decision to not include the $J$ Korean Soc Appl Bi in the overall analyses (this also applied to the new title that was adopted in 2016). And this is consistent with the results of the WC searches because the $J$ Korean Soc Appl Bi never appears in any of those searches, including 2010 and 2011 when the $J$ Korean Soc Appl Bi was correctly indexed in the JCR AE category.

However, a version of Figure 2 (Figure B.2) is shown in Appendix B that does include the $J$ Korean Soc Appl Bi for selected SO search years (2008 to 2011 and 2013 to 2016), which accounts for the rule stated above that a journal was indexed in the WoS CC AE category two years before it first appears in the JCR AE category.

6) Incorrect search results (under accounting) were obtained within SO searches when the abbreviated journal titles Eng Agr-Jaboticabal during 2008 to 2010 and J Irrig Drain Eng in 2009 and 2011 to 2013, as compared to the total articles found for those abbreviated titles in the respective WC searches (Table D.1).

Explanation: These journals had abbreviation changes in 2010 and 2013, respectively. This again points to the need to have more inclusive search structures (similar to \# 2 above), which in this case was facilitated by using the full journal titles.

Adjustment: The full journal titles were used for these two journals and in all of the pertinent SO searches. Ultimately, the full title was also used for Revista Brasileira de Engenharia Agricola e Ambiental for affected SO searchers, for the same reasons.

Following are the exact SO searches used for each year during the 2006 to 2016 time period:

2006: SO = (APPL ENG AGRIC or AQUACULT ENG or BIOMASS BIOENERG or BIORESOURCE TECHNOL or BIOSYST ENG or IND CROP PROD or IRRIGATION SCI or J IRRIG DRAIN ENG or T ASABE)

2007: SO = (AGRARTECH FORSCH-AGR or AMA-AGR MECH ASIA AF or APPL ENG AGRIC or AQUACULT ENG or BIOMASS BIOENERG or BIORESOURCE TECHNOL or BIOSYST ENG or IND CROP PROD or IRRIGATION SCI or J IRRIG DRAIN ENG or T ASABE)

2008: SO = (AMA-AGR MECH ASIA AF or APPL ENG AGRIC or AQUACULT ENG or BIOMASS BIOENERG or BIORESOURCE TECHNOL or BIOSYST ENG or ENGENHARIA AGRICOLA or IND CROP PROD or IRRIGATION SCI or J IRRIG DRAIN ENG or T ASABE)

2009: SO = (AMA-AGR MECH ASIA AF or APPL ENG AGRIC or AQUACULT ENG or BIOMASS BIOENERG or BIORESOURCE TECHNOL or BIOSYST ENG or ENGENHARIA AGRICOLA or IND CROP PROD or IRRIGATION SCI or J IRRIG DRAIN ENG or PADDY WATER ENVIRON or T ASABE)

2010: SO = (AMA-AGR MECH ASIA AF or APPL ENG AGRIC or AQUACULT ENG or BIOMASS BIOENERG or BIORESOURCE TECHNOL or BIOSYST ENG or ENGENHARIA AGRICOLA or IND CROP PROD or IRRIGATION SCI or J IRRIG DRAIN ENG or PADDY WATER ENVIRON or REVISTA BRASILEIRA DE ENGENHARIA AGRICOLA E AMBIENTAL or T ASABE) 
2011: SO = (AMA-AGR MECH ASIA AF or APPL ENG AGRIC or AQUACULT ENG or BIOMASS BIOENERG or BIORESOURCE TECHNOL or BIOSYST ENG or ENGENHARIA AGRICOLA or IND CROP PROD or J IRRIG DRAIN ENG or PADDY WATER ENVIRON or REVISTA BRASILEIRA DE ENGENHARIA AGRICOLA E AMBIENTAL or T ASABE)

2012: SO = (AMA-AGR MECH ASIA AF or APPL ENG AGRIC or AQUACULT ENG or BIOMASS BIOENERG or BIORESOURCE TECHNOL or BIOSYST ENG or ENGENHARIA AGRICOLA or IND CROP PROD or J IRRIG DRAIN ENG or PADDY WATER ENVIRON or REVISTA BRASILEIRA DE ENGENHARIA AGRICOLA E AMBIENTAL or T ASABE)

2013: SO = (AMA-AGR MECH ASIA AF or APPL ENG AGRIC or AQUACULT ENG or BIOMASS BIOENERG or BIORESOURCE TECHNOL or BIOSYST ENG or ENGENHARIA AGRICOLA or IND CROP PROD or INT J AGR BIOL ENG or J IRRIG DRAIN ENG or PADDY WATER ENVIRON or REVISTA BRASILEIRA DE ENGENHARIA AGRICOLA E AMBIENTAL or T ASABE)

2014: SO = (AMA-AGR MECH ASIA AF or APPL ENG AGRIC or AQUACULT ENG or BIOMASS BIOENERG or BIORESOURCE TECHNOL or BIOSYST ENG or ENGENHARIA AGRICOLA or IND CROP PROD or INT J AGR BIOL ENG or J IRRIG DRAIN ENG or PADDY WATER ENVIRON or REVISTA BRASILEIRA DE ENGENHARIA AGRICOLA E AMBIENTAL or T ASABE)

2015: SO = (AMA-AGR MECH ASIA AF or APPL ENG AGRIC or AQUACULT ENG or BIOMASS BIOENERG or BIORESOURCE TECHNOL or BIOSYST ENG or ENGENHARIA AGRICOLA or IND CROP PROD or INT J AGR BIOL ENG or J IRRIG DRAIN ENG or PADDY WATER ENVIRON or REVISTA BRASILEIRA DE ENGENHARIA AGRICOLA E AMBIENTAL or T ASABE)

2016: SO = (AMA-AGR MECH ASIA AF or APPL ENG AGRIC or AQUACULT ENG or BIOMASS BIOENERG or BIORESOURCE TECHNOL or BIOSYST ENG or ENGENHARIA AGRICOLA or IND CROP PROD or INT J AGR BIOL ENG or J IRRIG DRAIN ENG or PADDY WATER ENVIRON or REVISTA BRASILEIRA DE ENGENHARIA AGRICOLA E AMBIENTAL or T ASABE)

Table D.1 Total annual published articles reported for journals indexed in the WoS CC AE category using two different search options (described above): Web of Science Category (WC) or Publication Name (SO)

\begin{tabular}{|c|c|c|c|c|c|c|c|c|c|c|c|c|c|c|c|c|c|c|c|c|c|c|}
\hline \multirow{3}{*}{$\begin{array}{l}\text { Journal title (WoS } \\
\text { abbreviated name) }\end{array}$} & \multicolumn{22}{|c|}{ Year and type of search } \\
\hline & \multicolumn{2}{|c|}{2006} & \multicolumn{2}{|c|}{2007} & \multicolumn{2}{|c|}{2008} & \multicolumn{2}{|c|}{2009} & \multicolumn{2}{|c|}{2010} & \multicolumn{2}{|c|}{2011} & \multicolumn{2}{|c|}{2012} & \multicolumn{2}{|c|}{2013} & \multicolumn{2}{|c|}{2014} & \multicolumn{2}{|c|}{2015} & \multicolumn{2}{|c|}{2016} \\
\hline & WC & $\mathrm{SO}$ & WC & SO & WC & SO & WC & SO & WC & $\mathrm{SO}$ & WC & $\mathrm{SO}$ & WC & $\mathrm{SO}$ & WC & $\mathrm{SO}$ & WC & $\mathrm{SO}$ & WC & $\mathrm{SO}$ & WC & SO \\
\hline $\begin{array}{l}\text { AGRARTECH } \\
\text { FORSCH-AGR }\end{array}$ & 0 & 0 & 15 & 15 & 0 & 0 & 0 & 0 & 0 & 0 & 0 & 0 & 0 & 0 & 0 & 0 & 0 & 0 & 0 & 0 & 0 & 0 \\
\hline $\begin{array}{l}\text { AMA-AGR MECH } \\
\text { ASIA AF }\end{array}$ & 0 & 0 & 62 & 62 & 46 & 46 & 81 & 81 & 59 & 59 & 61 & 61 & 53 & 53 & 61 & 61 & 57 & 57 & 53 & 53 & 63 & 63 \\
\hline APPL BIOL CHEM $^{\mathrm{a}}$ & 0 & 0 & 0 & 0 & 0 & 0 & 0 & 0 & 0 & 0 & 0 & 0 & 0 & 0 & 0 & 0 & 0 & 0 & 0 & 0 & 0 & 111 \\
\hline APPL ENG AGRIC & 110 & 110 & 98 & 98 & 99 & 99 & 103 & 103 & 111 & 111 & 115 & 115 & 101 & 101 & 104 & 104 & 99 & 99 & 95 & 95 & 104 & 104 \\
\hline AQUACULT ENG & 63 & 63 & 59 & 59 & 34 & 34 & 43 & 43 & 34 & 34 & 30 & 30 & 39 & 39 & 67 & 67 & 60 & 60 & 52 & 52 & 45 & 45 \\
\hline $\begin{array}{l}\text { BIOMASS } \\
\text { BIOENERG }\end{array}$ & 127 & 127 & 95 & 95 & 147 & 147 & 203 & 203 & 231 & 231 & 570 & 570 & 433 & 433 & 391 & 391 & 418 & 418 & 356 & 356 & 317 & 317 \\
\hline $\begin{array}{l}\text { BIORESOURCE } \\
\text { TECHNOL }\end{array}$ & 337 & 337 & 509 & 509 & 1231 & 1231 & 1035 & 1035 & 1458 & 1458 & 1656 & 1656 & 1566 & 1566 & 1987 & 1987 & 1498 & 1498 & 1537 & 1537 & 1615 & 1615 \\
\hline BIOSYST ENG & 162 & 162 & 166 & 166 & 182 & 182 & 172 & 172 & 158 & 158 & 129 & 129 & 125 & 125 & 154 & 154 & 160 & 160 & 164 & 164 & 193 & 193 \\
\hline $\begin{array}{l}\text { ENG } \\
\text { AGR-JABOTICABAL }\end{array}$ & 0 & 0 & 0 & 0 & 77 & 77 & 70 & 70 & 97 & 97 & 121 & 121 & 120 & 120 & 124 & 124 & 122 & 122 & 113 & 113 & 125 & 125 \\
\hline IND CROP PROD & 82 & 82 & 78 & 78 & 108 & 108 & 166 & 166 & 191 & 191 & 244 & 244 & 322 & 322 & 879 & 879 & 574 & 574 & 937 & 937 & 713 & 713 \\
\hline INT J AGR BIOL ENG & 0 & 0 & 0 & 0 & 0 & 0 & 0 & 0 & 0 & 0 & 0 & 0 & 0 & 0 & 50 & 50 & 91 & 91 & 106 & 106 & 133 & 133 \\
\hline IRRIGATION SCI & 0 & 30 & 0 & 37 & 0 & 49 & 0 & 50 & 0 & 37 & 0 & 0 & 0 & 0 & 0 & 0 & 0 & 0 & 0 & 0 & 0 & 0 \\
\hline J IRRIG DRAIN ENG & 105 & 105 & 88 & 88 & 127 & 127 & 130 & 131 & 138 & 138 & 104 & 104 & 145 & 145 & 144 & 144 & 124 & 124 & 158 & 158 & 176 & 176 \\
\hline $\begin{array}{l}\text { J KOREAN SOC } \\
\text { APPL BI }^{\mathrm{a}}\end{array}$ & 0 & 0 & 0 & 0 & 0 & 63 & 0 & 122 & 0 & 130 & 0 & 152 & 0 & 0 & 0 & 115 & 0 & 120 & 0 & 122 & 0 & 0 \\
\hline $\begin{array}{l}\text { PADDY WATER } \\
\text { ENVIRON }\end{array}$ & 33 & 0 & 34 & 0 & 46 & 0 & 36 & 36 & 39 & 39 & 44 & 44 & 31 & 31 & 56 & 56 & 70 & 70 & 51 & 51 & 47 & 47 \\
\hline $\begin{array}{l}\text { REV BRAS ENG } \\
\text { AGR AMB }\end{array}$ & 0 & 0 & 0 & 0 & 0 & 0 & 0 & 0 & 179 & 179 & 180 & 180 & 180 & 180 & 180 & 180 & 194 & 194 & 180 & 180 & 180 & 180 \\
\hline T ASABE & 206 & 206 & 244 & 244 & 218 & 218 & 211 & 211 & 188 & 188 & 232 & 232 & 220 & 220 & 202 & 202 & 165 & 165 & 154 & 154 & 203 & 203 \\
\hline Totals & 1225 & 1222 & 1448 & 1451 & 2315 & 2381 & 2251 & 2423 & 2883 & 3050 & 3486 & 3638 & 3335 & 3335 & 4389 & 4504 & 3632 & 3752 & 3956 & 4078 & 3914 & 4025 \\
\hline
\end{tabular}

Appendix E. JCR citation data for selected journals indexed in the AE journal category (supporting information for data in Tables D.1).

Tables E.2 and E.3 provide citation data, obtained from the overall 2017 JCR data, that list the specific number of citations for two categories: Cited Journal Data and Citing Journal Data ${ }^{[101,102]}$. These two categories are described as follows:

1) Cited Journal Data: The number of citations that a journal received in a specific year, which includes the aggregate number of citations that the journal receives from all journals (identified as "all" in the top rows of Tables E.2 and E.3) and the number of citations the journal receives from other specific journals. 
2) Citing Journal Data: The number of citations that occur from articles published in a journal to other journals in a specific year, which includes the aggregate number of citations that occur from the journal to all other journals (identified as "all" in the top rows of Tables E.2 and E.3) and the number of citations that occur from the journal to other specific journals.

A ranking is included with the journals shown in Tables E.2 and E.3, which is based on the total number of citations that occurred for that respective journal in either the Cited Journal Data or Citing Journal Data categories. These citations are based on the "all years" column for the Cited Journal Data or Citing Journal Data, which includes data extending back from 2016 for over a decade (specific citation data is shown for both categories in the JCR for the 10 years between 2016 and 2007). A common occurrence for both categories are journals with the same number of citations; e.g., there are dozens of journals listed within the Cited Journal Data category which are listed as having provided two citations each to articles that were published in Bioresource Tech in 2016. In these situations, the rankings are based on alphabetical order, resulting in journals credited with the same number of citations that are ranked at different levels (e.g., see the Int $J$ Agr Biol Eng data columns in Table E.3). These "citation ties" also affect the relative rankings of journals below where the ties occurred in either the Cited Journal Data or Citing Journal Data column. One other odd citation quirk is the fact that citation data is sometimes reported more than once for a specific journal, due to a journal name change or a change in journal abbreviation within the JCR. Citation data affected by multiple name occurrences are indicated via footnotes in Tables E.2 and E.3.

The citation data listed in Table E.2 date was obtained from the 2017 JCR for Bioresource Technol, Ind Crop Prod and Biomass Bioenerg, to allow evaluation of citation patterns between those three journals and to four key comprehensive AE journals: Appl Eng Agric, Biosyst Eng, Int J Agr Biol Eng and T ASABE. The citation data in Table E.3 date was obtained for Appl Eng Agric, Biosyst Eng, Int J Agr Biol Eng and T ASABE, to support evaluation of citation patterns between those four journals, the remaining JCR AE journals (Table 1) and the journals listed in Table E.1. The additional journals shown in Table E.1 were included due to discernible patterns of relatively strong citation relationships between those journals and Appl Eng Agric, Biosyst Eng, Int J Agr Biol Eng and T ASABE. The JCR AE category journals are shown in bold text in Table E.3.

Table E.1 Additional journals included in Table E.3, for comparisons of citation patterns between Appl Eng Agric, Biosyst Eng, Int J Agr Biol Eng and TASABE, and the other nine journals included in the 2017 JCR AE category

\begin{tabular}{|c|c|c|c|c|}
\hline Full journal title & Abbreviated journal title & Publisher (country) & Publication Frequency & JCR categories \\
\hline Agricultural Water Management & Agr Water Manage & Elsevier B.V. (The Netherlands) & Monthly to < monthly & Agronomy; Water Resources \\
\hline $\begin{array}{l}\text { Computers and Electronics in } \\
\text { Agriculture }\end{array}$ & Comput Electron Agr & Elsevier B.V. (The Netherlands) & Monthly to $<$ monthly & $\begin{array}{l}\text { Agriculture, Multidisciplinary; Computer } \\
\text { Science, Interdisciplinary Applications }\end{array}$ \\
\hline Irrigation Science & Irrigation Sci & Springer Verlag (Germany) & Bimonthly & Agronomy; Water Resources \\
\hline Journal of Environmental Quality & J Environ Qual & ASA, CSSA and SSSA ${ }^{a}$ & Bimonthly & Environmental Sciences \\
\hline Journal of Food Engineering & J Food Eng & Elsevier B.V. (The Netherlands) & Biweekly & $\begin{array}{l}\text { Engineering, Chemical; Food Science and } \\
\text { Technology }\end{array}$ \\
\hline $\begin{array}{l}\text { Journal of Soil and Water } \\
\text { Conservation }\end{array}$ & J Soil Water Conser & $\begin{array}{l}\text { Soil and Water Conservation } \\
\text { Society }\end{array}$ & Bimonthly & Ecology; Soil Science; Water Resources \\
\hline Precision Agriculture & Precis Agric & Springer Verlag (Germany) & Bimonthly & Agriculture, Multidisciplinary \\
\hline $\begin{array}{l}\text { Soil Science Society of America } \\
\text { Journal }\end{array}$ & Soil Sci Soc Am J & Soil Science Society of America & Bimonthly & Soil Science \\
\hline
\end{tabular}

Note: ${ }^{a}$ ASA = American Society of Agronomy; CSSA = Crop Science Society of America; SSSA = Soil Science Society of America.

Table E.2 Key Cited Journal Data and Citing Journal Data, for Bioresource Technol, Biomass Bioenerg and Ind Crop Prod, in relation to each other and four primary comprehensive AE journals: Appl Eng Agric, Biosyst Eng, Int J Agr Biol Eng and T ASABE

\begin{tabular}{|c|c|c|c|c|c|c|c|c|c|c|c|}
\hline \multicolumn{4}{|c|}{ Bioresource Technol } & \multicolumn{4}{|c|}{ Biomass Bioenerg } & \multicolumn{4}{|c|}{ Ind Crop Prod } \\
\hline \multicolumn{2}{|c|}{ Cited Journal Data } & \multicolumn{2}{|c|}{ Citing Journal Data } & \multicolumn{2}{|c|}{ Cited Journal Data } & \multicolumn{2}{|c|}{ Citing Journal Data } & \multicolumn{2}{|c|}{ Cited Journal Data } & \multicolumn{2}{|c|}{ Citing Journal Data } \\
\hline Journal (rank) & Citations & Journal (rank) & Citations & $\begin{array}{c}\text { Journal } \\
\text { (rank) }\end{array}$ & Citations & Journal (rank) & Citations & Journal (rank) & Citations & Journal (rank) & Citations \\
\hline All journals ${ }^{\mathrm{a}}$ & 93612 & All journals & 55413 & All journals & 18312 & All Journals & 14125 & All Journals & 15116 & All Journals & 31235 \\
\hline $\begin{array}{l}\text { Bioresource } \\
\text { Tech (1) }\end{array}$ & 11644 & $\begin{array}{l}\text { Bioresource } \\
\text { Tech (1) }\end{array}$ & 11644 & $\begin{array}{c}\text { Biomass } \\
\text { Bioenerg (2) }\end{array}$ & 994 & $\begin{array}{c}\text { Bioresource } \\
\text { Tech (1) }\end{array}$ & 1016 & $\begin{array}{l}\text { Ind Crop Prod } \\
\text { (1) }\end{array}$ & 1609 & $\begin{array}{l}\text { Ind Crop Prod } \\
\text { (1) }\end{array}$ & 1609 \\
\hline $\begin{array}{c}\text { Biomass } \\
\text { Bioenerg (12) }\end{array}$ & 1016 & $\begin{array}{c}\text { Biomass } \\
\text { Bioenerg (7) }\end{array}$ & 791 & $\begin{array}{c}\text { Bioresource } \\
\text { Tech (3) }\end{array}$ & 791 & $\begin{array}{c}\text { Biomass } \\
\text { Bioenerg (2) }\end{array}$ & 994 & $\begin{array}{c}\text { Bioresource } \\
\text { Tech (4) }\end{array}$ & 273 & $\begin{array}{l}\text { Bioresource } \\
\text { Tech (2) }\end{array}$ & 872 \\
\hline $\begin{array}{l}\text { Ind Crop } \\
\text { Prod (20) }\end{array}$ & 872 & $\begin{array}{c}\text { Ind Crop Prod } \\
\text { (34) }\end{array}$ & 273 & $\begin{array}{l}\text { Ind Crop } \\
\text { Prod (14) }\end{array}$ & 297 & $\begin{array}{c}\text { Ind Crop Prod } \\
\text { (17) }\end{array}$ & 91 & $\begin{array}{c}\text { Biomass } \\
\text { Bioenerg (19) }\end{array}$ & 91 & $\begin{array}{c}\text { Biomass } \\
\text { Bioenerg (9) }\end{array}$ & 247 \\
\hline $\begin{array}{l}\text { T ASABE } \\
\text { (173) }\end{array}$ & 80 & $\begin{array}{l}\text { T ASABE } \\
\text { (182) }\end{array}$ & 36 & $\begin{array}{c}\text { T ASABE } \\
(87)\end{array}$ & 33 & $\begin{array}{c}\text { Biosyst Eng } \\
\text { (83) }\end{array}$ & 21 & $\begin{array}{l}\text { T ASABE } \\
\text { (188) }\end{array}$ & 17 & $\begin{array}{l}\text { T ASABE } \\
(225)\end{array}$ & 22 \\
\hline $\begin{array}{l}\text { Int J Agr Biol } \\
\text { Eng (255) }\end{array}$ & 45 & $\begin{array}{c}\text { Biosyst Eng } \\
\text { (194) }\end{array}$ & 31 & $\begin{array}{c}\text { Biosyst Eng } \\
\text { (156) }\end{array}$ & 19 & T ASABE (93) & 20 & $\begin{array}{c}\text { Biosyst Eng } \\
\text { (215) }\end{array}$ & 14 & $\begin{array}{c}\text { Biosyst Eng } \\
\text { (328) }\end{array}$ & 13 \\
\hline $\begin{array}{l}\text { Biosyst Eng } \\
\text { (283) }\end{array}$ & 38 & $\begin{array}{l}\text { Int J Agr Biol } \\
\text { Eng (475) }\end{array}$ & 8 & $\begin{array}{c}\text { Int J Agr Biol } \\
\text { Eng (224) }\end{array}$ & 13 & $\begin{array}{l}\text { Appl Eng Agric } \\
(107)\end{array}$ & 16 & $\begin{array}{c}\text { Int J Agr Biol } \\
\text { Eng (257) }\end{array}$ & 12 & $\begin{array}{c}\text { Appl Eng } \\
\text { Agric (383) }\end{array}$ & 11 \\
\hline $\begin{array}{c}\text { Appl Eng } \\
\text { Agric (488) }\end{array}$ & 19 & $\begin{array}{c}\text { Appl Eng } \\
\text { Agric (558) }\end{array}$ & 6 & $\begin{array}{c}\text { Appl Eng } \\
\text { Agric (490) }\end{array}$ & 4 & $\begin{array}{l}\text { Int J Agr Biol } \\
\text { Eng (469) }\end{array}$ & 3 & $\begin{array}{c}\text { Appl Eng Agric } \\
(419)\end{array}$ & 6 & $\begin{array}{l}\text { Int J Agr Biol } \\
\text { Eng (394) }\end{array}$ & 11 \\
\hline
\end{tabular}

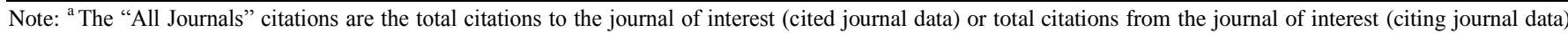
across all of the journals and all of the years that are recorded in the JCR database. 
Table E.3 Key Cited Journal Data and Citing Journal Data, for Appl Eng Agric, Biosyst Eng, Int J Agr Biol Eng and T ASABE, in relation to the top ten journals and other JCR AE category journals

\begin{tabular}{|c|c|c|c|c|c|c|c|c|c|c|c|c|c|c|c|}
\hline \multicolumn{4}{|c|}{ Appl Eng Agric } & \multicolumn{4}{|c|}{ Biosyst Eng } & \multicolumn{4}{|c|}{ Int J Agr Biol Eng } & \multicolumn{4}{|c|}{ T ASABE } \\
\hline \multicolumn{2}{|c|}{ Cited Journal Data } & \multicolumn{2}{|c|}{ Citing Journal Data } & \multicolumn{2}{|c|}{ Cited Journal Data } & \multicolumn{2}{|c|}{ Citing Journal Data } & \multicolumn{2}{|c|}{ Cited Journal Data } & \multicolumn{2}{|c|}{ Citing Journal Data } & \multicolumn{2}{|c|}{ Cited Journal Data } & \multicolumn{2}{|c|}{ Citing Journal Data } \\
\hline $\begin{array}{l}\text { Journal } \\
\text { (rank) }\end{array}$ & Cites $^{\mathrm{a}}$ & $\begin{array}{l}\text { Journal } \\
\text { (rank) }\end{array}$ & Cites & $\begin{array}{c}\text { Journal } \\
\text { (rank) }\end{array}$ & Cites & $\begin{array}{c}\text { Journal } \\
\text { (rank) }\end{array}$ & Cites & $\begin{array}{l}\text { Journal } \\
\text { (rank) }\end{array}$ & Cites & $\begin{array}{c}\text { Journal } \\
\text { (rank) }\end{array}$ & Cites & $\begin{array}{l}\text { Journal } \\
\text { (rank) }\end{array}$ & Cites & $\begin{array}{c}\text { Journal } \\
\text { (rank) }\end{array}$ & Cites \\
\hline $\mathrm{All}^{\mathrm{b}}$ & 1,590 & All & 3,113 & All & 4,495 & All & 7,621 & All & 503 & All & 4,106 & All & 8,412 & All & 7,705 \\
\hline $\begin{array}{c}\text { T ASABE } \\
\text { (1) }\end{array}$ & 164 & $\begin{array}{c}\text { T ASABE } \\
\text { (1) }\end{array}$ & 187 & $\begin{array}{l}\text { Biosyst Eng } \\
\text { (1) }\end{array}$ & 456 & $\begin{array}{l}\text { Biosyst Eng } \\
\text { (1) }\end{array}$ & $564^{\mathrm{c}}$ & $\begin{array}{c}\text { Int J Agr } \\
\text { Biol Eng (1) }\end{array}$ & 116 & $\begin{array}{c}\text { Int J Agr } \\
\text { Biol Eng (2) }\end{array}$ & $124^{\mathrm{c}}$ & $\underset{(1)}{\text { T ASABE }}$ & 612 & $\underset{(1)}{\text { T ASABE }}$ & 612 \\
\hline $\begin{array}{l}\text { Appl Eng } \\
\text { Agric (2) }\end{array}$ & 107 & $\begin{array}{l}\text { Appl Eng } \\
\text { Agric (2) }\end{array}$ & 107 & $\begin{array}{c}\text { Comput } \\
\text { Electron Agr } \\
\text { (2) }\end{array}$ & 226 & $\begin{array}{l}\text { Comput } \\
\text { Electron Agr } \\
\text { (2) }\end{array}$ & $303^{c}$ & $\begin{array}{c}\text { T ASABE } \\
(3)\end{array}$ & 11 & $\begin{array}{c}\text { Biosyst Eng } \\
\text { (3) }\end{array}$ & $111^{c}$ & $\begin{array}{l}\text { Agr Water } \\
\text { Manage (2) }\end{array}$ & 271 & $\begin{array}{l}\text { Appl Eng } \\
\text { Agric (2) }\end{array}$ & $171^{\mathrm{c}}$ \\
\hline $\begin{array}{l}\text { Comput } \\
\text { Electron Agr } \\
\text { (3) }\end{array}$ & 53 & $\begin{array}{c}\text { Biosyst Eng } \\
\text { (3) }\end{array}$ & $75^{c}$ & $\begin{array}{c}\text { Int J Agr } \\
\text { Biol Eng (4) }\end{array}$ & 87 & $\begin{array}{c}\text { T ASABE } \\
(\mathbf{3})\end{array}$ & 241 & $\begin{array}{c}\text { Bio- } \\
\text { resource } \\
\text { Tech (4) }\end{array}$ & 8 & $\begin{array}{l}\text { Comput } \\
\text { Electron } \\
\text { Agr (7) }\end{array}$ & $77^{\mathrm{c}}$ & $\begin{array}{l}\text { Comput } \\
\text { Electron } \\
\text { Agr (3) }\end{array}$ & 267 & $\begin{array}{c}\text { Biosyst Eng } \\
\text { (8) }\end{array}$ & $142^{\mathrm{c}}$ \\
\hline $\begin{array}{c}\text { Biosyst Eng } \\
\text { (4) }\end{array}$ & 52 & $\begin{array}{l}\text { Soil Sci Soc } \\
\text { Am J (4) }\end{array}$ & 43 & $\underset{(5)}{\text { T ASABE }}$ & 84 & $\begin{array}{l}\text { J Food Eng } \\
\text { (4) }\end{array}$ & 126 & $\begin{array}{l}\text { Comput } \\
\text { Electron } \\
\text { Agr (5) }\end{array}$ & 8 & $\begin{array}{c}\text { T ASABE } \\
(\mathbf{8})\end{array}$ & 64 & $\begin{array}{l}\text { Biosyst } \\
\text { Eng (5) }\end{array}$ & 241 & $\begin{array}{l}\text { Agr Water } \\
\text { Manage (4) }\end{array}$ & 105 \\
\hline $\begin{array}{l}\text { J Environ } \\
\text { Qual (5) }\end{array}$ & 38 & $\begin{array}{l}\text { J Environ } \\
\text { Qual (5) }\end{array}$ & 42 & $\begin{array}{l}\text { J Food Eng } \\
\quad(6)\end{array}$ & 63 & $\begin{array}{l}\text { Appl Eng } \\
\text { Agric (10) }\end{array}$ & 52 & $\begin{array}{l}\text { Appl Eng } \\
\text { Agric (9) }\end{array}$ & 4 & $\begin{array}{c}\text { Agr Water } \\
\text { Manage (9) }\end{array}$ & 55 & $\begin{array}{l}\text { Appl Eng } \\
\text { Agric (6) }\end{array}$ & 187 & $\begin{array}{c}\text { Comput } \\
\text { Electron Agr } \\
\text { (6) }\end{array}$ & 89 \\
\hline $\begin{array}{l}\text { Agr Water } \\
\text { Manage (6) }\end{array}$ & 37 & $\begin{array}{c}\text { J Irrig } \\
\text { Drain Eng } \\
(7)\end{array}$ & 32 & $\begin{array}{l}\text { Appl Eng } \\
\text { Agric (8) }\end{array}$ & 50 & $\begin{array}{c}\text { Precis Agric } \\
\text { (12) }\end{array}$ & 45 & $\begin{array}{c}\text { Biosyst Eng } \\
\text { (10) }\end{array}$ & 4 & $\begin{array}{c}\text { J Food Eng } \\
(10)\end{array}$ & 51 & $\begin{array}{c}\text { J Irrig } \\
\text { Drain Eng } \\
\text { (11) }\end{array}$ & 123 & $\begin{array}{l}\text { J Food Eng } \\
\text { (7) }\end{array}$ & 87 \\
\hline $\begin{array}{c}\text { Int J Agr } \\
\text { Biol Eng (7) }\end{array}$ & 26 & $\begin{array}{l}\text { Agr Water } \\
\text { Manage (8) }\end{array}$ & 31 & $\begin{array}{c}\text { Agr Water } \\
\text { Manage (8) }\end{array}$ & 31 & $\begin{array}{l}\text { Soil Sci Soc } \\
\text { Am J (14) }\end{array}$ & 42 & $\begin{array}{l}\text { Ind Crop } \\
\text { Prod (15) }\end{array}$ & 4 & $\begin{array}{c}\text { Bio- } \\
\text { resource } \\
\text { Tech }(11)\end{array}$ & 45 & $\begin{array}{l}\text { J Environ } \\
\text { Qual (12) }\end{array}$ & 117 & $\begin{array}{c}\text { Biosyst Eng } \\
\text { (8) }\end{array}$ & 84 \\
\hline $\begin{array}{c}\text { Biomass } \\
\text { Bioenerg (9) }\end{array}$ & 16 & $\begin{array}{l}\text { Comp } \\
\text { Electron Agr } \\
\quad(11)\end{array}$ & 29 & $\begin{array}{c}\text { Bio- } \\
\text { resource } \\
\text { Tech (19) }\end{array}$ & 31 & $\begin{array}{l}\text { Bio-resourc } \\
\text { e Tech (18) }\end{array}$ & 38 & $\begin{array}{c}\text { Agr Water } \\
\text { Manage (20) }\end{array}$ & 3 & $\begin{array}{l}\text { Appl Eng } \\
\text { Agric (15) }\end{array}$ & 26 & $\begin{array}{l}\text { Int J Agr } \\
\text { Biol Eng } \\
\quad(18)\end{array}$ & 64 & $\begin{array}{c}\text { J Environ } \\
\text { Qual (9) }\end{array}$ & 81 \\
\hline $\begin{array}{l}\text { J Irrig Drain } \\
\text { Eng (17) }\end{array}$ & 16 & $\begin{array}{l}\text { J Food Eng } \\
\text { (15) }\end{array}$ & 24 & $\begin{array}{l}\text { J Environ } \\
\text { Qual (21) }\end{array}$ & 30 & $\begin{array}{c}\text { Agr Water } \\
\text { Manage (25) }\end{array}$ & 29 & $\begin{array}{l}\text { Biomass } \\
\text { Bioenerg } \\
\quad(22)\end{array}$ & 3 & $\begin{array}{l}\text { Irrigation } \\
\text { Sci (26) }\end{array}$ & 17 & $\begin{array}{l}\text { Soil Sci Soc } \\
\text { Am J (24) }\end{array}$ & 52 & $\begin{array}{c}\text { Bio-resource } \\
\text { Tech (10) }\end{array}$ & 80 \\
\hline $\begin{array}{c}\text { AMA-Agr } \\
\text { Mech Asia } \\
\text { AF (30) }\end{array}$ & 8 & $\begin{array}{c}\text { Precis Agric } \\
\text { (29) }\end{array}$ & 12 & $\begin{array}{c}\text { Precis Agric } \\
\text { (39) }\end{array}$ & 17 & $\begin{array}{c}\text { Biomass } \\
\text { Bioenerg } \\
\quad(45)\end{array}$ & 19 & & & $\begin{array}{l}\text { Soil Sci Soc } \\
\text { Am J (26) }\end{array}$ & 16 & $\begin{array}{l}\text { J Soil Water } \\
\text { Conserv } \\
(34)\end{array}$ & 10 & $\begin{array}{l}\text { Irrigation Sci } \\
\text { (18) }\end{array}$ & 49 \\
\hline $\begin{array}{c}\text { Bio- } \\
\text { resource } \\
\text { Technol (47) }\end{array}$ & 6 & $\begin{array}{l}\text { J Soil Water } \\
\text { Conserv (34) }\end{array}$ & 10 & $\begin{array}{c}\text { Eng Agr- } \\
\text { Jabotical } \\
(49)\end{array}$ & 17 & $\begin{array}{l}\text { Irrigation Sci } \\
\qquad(53)\end{array}$ & 6 & & & $\begin{array}{c}\text { Biomass } \\
\text { Bioenerg } \\
\quad(31)\end{array}$ & 13 & $\begin{array}{c}\text { Bio-resour } \\
\text { ce Tech } \\
(37)\end{array}$ & 36 & $\begin{array}{l}\text { J Irrig } \\
\text { Drain Eng } \\
(20)\end{array}$ & 46 \\
\hline $\begin{array}{l}\text { Irrigation Sci } \\
\text { (53) }\end{array}$ & 6 & $\begin{array}{l}\text { Irrigation Sci } \\
\text { (40) }\end{array}$ & 9 & $\begin{array}{l}\text { Ind Crop } \\
\text { Prod (67) }\end{array}$ & 13 & $\begin{array}{l}\text { Ind Crop } \\
\text { Prod (57) }\end{array}$ & 14 & & & $\begin{array}{c}\text { AMA-Agr } \\
\text { Mech Asia } \\
\text { AF (35) }\end{array}$ & 12 & $\begin{array}{l}\text { J Soil Water } \\
\text { Conserv } \\
(34)\end{array}$ & 10 & $\begin{array}{c}\text { Biomass } \\
\text { Bioenerg } \\
(24)\end{array}$ & 33 \\
\hline $\begin{array}{l}\text { Precis Agric } \\
\quad(56)\end{array}$ & 6 & $\begin{array}{l}\text { Ind Crop } \\
\text { Prod (65) }\end{array}$ & 6 & $\begin{array}{l}\text { Rev Bras } \\
\text { Eng Agr } \\
\text { Amb (69) }\end{array}$ & 13 & $\begin{array}{l}\text { J Environ } \\
\text { Qual (67) }\end{array}$ & 13 & & & $\begin{array}{l}\text { Ind Crop } \\
\text { Prod (37) }\end{array}$ & 12 & $\begin{array}{c}\text { Bio-resour } \\
\text { ce Tech } \\
(37)\end{array}$ & 36 & $\begin{array}{l}\text { J Soil Water } \\
\text { Conserv (25) }\end{array}$ & 33 \\
\hline $\begin{array}{c}\text { J Food Eng } \\
(67)\end{array}$ & 5 & $\begin{array}{c}\text { Rev Bras } \\
\text { Eng Agr } \\
\text { Amb (84) }\end{array}$ & 5 & $\begin{array}{l}\text { J Irrig } \\
\text { Drain Eng } \\
(80)\end{array}$ & 11 & $\begin{array}{c}\text { Int J Agr } \\
\text { Biol Eng } \\
\quad(245)\end{array}$ & 4 & & & $\begin{array}{c}\text { Eng Agr- } \\
\text { Jabotical } \\
(312)\end{array}$ & 2 & $\begin{array}{l}\text { Irrigation } \\
\text { Sci (38) }\end{array}$ & 36 & $\begin{array}{l}\text { Aquacult } \\
\text { Eng (49) }\end{array}$ & 18 \\
\hline $\begin{array}{l}\text { J Soil Water } \\
\text { Conserv (71) }\end{array}$ & 5 & $\begin{array}{l}\text { Biomass } \\
\text { Bioenerg } \\
\quad(87)\end{array}$ & 4 & $\begin{array}{l}\text { Soil Sci Soc } \\
\text { Am J (84) }\end{array}$ & 11 & $\begin{array}{l}\text { J Soil Water } \\
\text { Conserv (34) }\end{array}$ & 10 & & & $\begin{array}{l}\text { J Soil Water } \\
\text { Conserv } \\
(372)\end{array}$ & $4^{\mathrm{c}}$ & $\begin{array}{c}\text { AMA-Agr } \\
\text { Mech Asia } \\
\text { AF (53) }\end{array}$ & 25 & $\begin{array}{l}\text { Ind Crop } \\
\text { Prod (56) }\end{array}$ & 17 \\
\hline $\begin{array}{c}\text { Rev Bras } \\
\text { Eng Agr } \\
\text { Amb (90) }\end{array}$ & 4 & $\begin{array}{l}\text { Int J Agr } \\
\text { Biol Eng } \\
\quad(93)\end{array}$ & 4 & $\begin{array}{c}\text { AMA-Agr } \\
\text { Mech Asia } \\
\text { AF (87) }\end{array}$ & 10 & $\begin{array}{c}\text { AMA-Agr } \\
\text { Mech Asia } \\
\text { AF (445) }\end{array}$ & 2 & & & $\begin{array}{c}\text { Paddy } \\
\text { Water } \\
\text { Environ } \\
(\mathbf{3 9 3})\end{array}$ & 2 & $\begin{array}{l}\text { Ind Crop } \\
\text { Prod (66) }\end{array}$ & 22 & $\begin{array}{c}\text { Precis Agric } \\
\text { (75) }\end{array}$ & 13 \\
\hline $\begin{array}{c}\text { Eng Agr- } \\
\text { Jabotical } \\
\quad(106)\end{array}$ & 3 & $\begin{array}{c}\text { AMA-Agr } \\
\text { Mech Asia } \\
\text { AF (112) }\end{array}$ & 3 & $\begin{array}{l}\text { Irrigation Sci } \\
\qquad(105)\end{array}$ & 9 & $\begin{array}{l}\text { Aquacult } \\
\text { Eng (457) }\end{array}$ & 2 & & & & & $\begin{array}{c}\text { Rev Bras } \\
\text { Eng Agr } \\
\text { Amb (72) }\end{array}$ & 21 & $\begin{array}{l}\text { Int J Agr } \\
\text { Biol Eng } \\
\quad(86)\end{array}$ & 11 \\
\hline \multirow[t]{2}{*}{$\begin{array}{l}\text { Aquacult } \\
\text { Eng (136) }\end{array}$} & 2 & & & $\begin{array}{l}\text { Paddy Water } \\
\text { Environ } \\
(294)\end{array}$ & 3 & & & & & & & $\begin{array}{c}\text { Biomass } \\
\text { Bioenerg } \\
(74)\end{array}$ & 20 & $\begin{array}{c}\text { Rev Bras } \\
\text { Eng Agr } \\
\text { Amb (273) }\end{array}$ & 4 \\
\hline & & & & & & & & & & & & $\begin{array}{l}\text { Eng Agr- } \\
\text { Jabotical } \\
\quad(94)\end{array}$ & 17 & $\begin{array}{c}\text { Eng Agr- } \\
\text { Jabotical } \\
(494)\end{array}$ & 2 \\
\hline
\end{tabular}


Note: ${ }^{\mathrm{a}}$ cites $=$ citations

b The "All" citations are the total citations to the journal of interest (cited journal data) or total citations from the journal of interest (citing journal data) across all of the journals and all of the years that are recorded in the JCR database.

${ }^{\mathrm{c}}$ Several of the citation values in Table E. 3 represent combinations of two different citation amounts recorded for the same journal, due to some of the citations being recorded for a previous name of an existing journal (e.g., J Agr Eng Res was the previous name of Biosyst Eng) or due to a change in the abbreviation used for a journal name in the JCR (also discussed in further detail in Appendix D). The specific Table E.3 citation values that were affected by these changes are described as a function of a specific data column:

Appl Eng Agr/Citing Journal Data: 75 cites (Biosyst Eng) = 50 cites (Biosyst Eng) +25 cites (J Agr Eng Res)

Biosyst Eng/Citing Journal Data: 564 cites (Biosyst Eng) = 456 cites (Biosyst Eng) +108 cites (J Agr Eng Res)

Biosyst Eng/Citing Journal Data: 303 cites (Comput Electron Agr) = 281 cites (Comput Electron Agr) + 22 cites (Computers Elect Agr)

Int J Agr Biol Eng/Citing Journal Data: 124 cites (Int J Agr Biol Eng) = 116 cites (Int J Agr Biol Eng) + 8 cites (Int J Agric Biol Eng)

Int J Agr Biol Eng/Citing Journal Data: 111 cites (Biosyst Eng) = 87 cites (Biosyst Eng) + 24 cites (J Agr Eng Res)

Int J Agr Biol Eng/Citing Journal Data: 77 cites (Comput Electron Agr) = 64 cites (Comput Electron Agr) + 13 cites (Computers Elect Agr)

Int J Agr Biol Eng/Citing Journal Data: 4 cites (J Soil Water Conserv) = 2 cites (J Soil Water Conserv) +2 cites (J Soils Water Conser)

T ASABE/Citing Journal Data: 171 cites (Appl Eng Agr) = 164 cites (Appl Eng Agr) +7 (Appl Eng Agr in press)

T ASABE/Citing Journal Data: 142 cites (Biosyst Eng) = 84 cites (Biosyst Eng) +58 cites (J Agr Eng Res) 